\title{
Oral Health-Related Quality of Life in Children and Adolescents with a Traumatic Injury of Permanent Teeth and the Impact on Their Families: A Systematic Review
}

\author{
Priyankaa Das ${ }^{1}$, Lora Mishra ${ }^{1, *}+\mathbb{C}$, Debkant Jena ${ }^{1}$, Shashirekha Govind ${ }^{1}$, Saurav Panda ${ }^{2}$ \\ and Barbara Lapinska ${ }^{3, *,+} \mathbb{D}$
}

1 Department of Conservative Dentistry and Endodontics, Institute of Dental Sciences, Siksha 'O' Anusandhan, Bhubaneswar 751003, Odisha, India; priyankaa.das053@gmail.com (P.D.); debkantjena@soa.ac.in (D.J.); shashirekhag@soa.ac.in (S.G.)

2 Department of Periodontics, Institute of Dental Sciences, Siksha 'O' Anusandhan, Bhubaneswar 751003, Odisha, India; sauravpanda@soa.ac.in

3 Department of General Dentistry, Medical University of Lodz, 92-213 Lodz, Poland

* Correspondence: loramishra@soa.ac.in (L.M.); barbara.lapinska@umed.lodz.pl (B.L.); Tel.: +91-889-526-6363 (L.M.); +85-42-675-74-61 (B.L.)

+ These authors contributed equally to this work.

check for updates

Citation: Das, P.; Mishra, L.; Jena, D.; Govind, S.; Panda, S.; Lapinska, B. Oral Health-Related Quality of Life in Children and Adolescents with a Traumatic Injury of Permanent Teeth and the Impact on Their Families: A Systematic Review. Int. J. Environ. Res. Public Health 2022, 19, 3087. https://doi.org/10.3390/ ijerph19053087

Academic Editors:

Yolanda Martinez Beneyto,

Antonio J. Ortiz Ruiz

and Ascensión Vicente Hernandez

Received: 20 January 2022

Accepted: 3 March 2022

Published: 6 March 2022

Publisher's Note: MDPI stays neutral with regard to jurisdictional claims in published maps and institutional affiliations.

Copyright: (C) 2022 by the authors. Licensee MDPI, Basel, Switzerland. This article is an open access article distributed under the terms and conditions of the Creative Commons Attribution (CC BY) license (https:/ / creativecommons.org/licenses/by/ $4.0 /)$.

\begin{abstract}
The aim of this systematic review was to evaluate the impact of a traumatic dental injury (TDI) of permanent teeth in children and adolescents on their oral health-related quality of life (OHRQoL) as well as on their families. A bibliographic search in the biomedical databases (PubMed, Cochrane Library, MEDLINE) was limited to studies published between January 2000 and February 2021. The study selection criteria were cross-sectional, case control, or prospective clinical studies, which analyzed TDI before and after the treatment of permanent teeth in healthy children and adolescent, assessed their OHRQoL, and were written in English. The search found 25 eligible articles that were included in the study. The quality assessment of the studies was performed using the quality assessment checklist for survey studies in psychology (Q-SSP). The results indicated that a TDI of permanent teeth strongly influences the OHRQoL of children and adolescents, and the timely-performed dental management of a TDI allows for preventing further biological and socio-psychological impacts. Sociodemographic status, economic status, parent's education, gender, age group, and type of schooling were determinants of the TDI impact on OHRQoL.
\end{abstract}

Keywords: oral health; quality of life; dental trauma; traumatic dental injury; permanent teeth; children; adolescent; well-being; systematic review; meta-analysis

\section{Introduction}

Quality of life is described as "an individual's perception of their place in life concerning goals, aspirations, standards, and concerns in the sense of the culture and values in which they reside" [1]. The definition of oral health-related quality of life (OHRQoL) refers to how oral health or disease affects an individual's everyday work, well-being, and, as a result, their overall quality of life [2]. The quality of life is highly affected by their state of health. Physical and psychological constraints in the field of dentistry can directly affect eating, speech, social interaction, and self-esteem [3]. A traumatic dental injury (TDI) is an irreversible disease that is attracting more consideration from health practitioners at the moment [4]. A TDI, especially in children, is considered a severe health issue. Maxillary anterior teeth are the most affected teeth that cause physical, aesthetic, and psychological problems for children and their parents [5,6]. The quality of life is a complex process, and each person's self-perceptions are shaped by their experiences, future expectations, dreams, and lifestyle [7]. Besides that, people change their view of their OHRQoL over time [8]. The second-most prevalent TDI is a crown fracture involving enamel and dentin (CFED). 
It is associated with trouble feeding, avoidance of smiling, sensitivity and discomfort, and a higher prevalence of adverse effects on OHRQoL $[9,10]$. Traumatic dental injuries to permanent teeth are more frequent than in primary dentition [11,12]. Dental injuries primarily concern the maxillary anterior teeth. Falls, sporting events, road traffic accidents, and bicycling are the most common causes of these injuries. Dental trauma predisposing factors may be related to the anatomical characteristics of the individual, such as increased overjet, insufficient lip coverage of the upper anterior teeth, etc. [13,14]. Home and school are areas where dental accidents frequently occur. It was observed that the place of injury was gender-related, i.e., the school followed by the home was the most common place of injury for boys, whereas this finding is vice versa for girls [15-17].

In everyday dental practice, treating dental injuries is not an ordinary condition. The result of the procedure is closely linked to the dentist's expertise and skills and the medical assistance at the injury site. Thus, the dentist, parents, teachers, and coaches must have basic knowledge of dental trauma emergency management. However, the rareness of a TDI and the uncertainty of treatment prognosis, an individual with a traumatized tooth becomes a concern for the dentist. It is not a routine operation for most dentists and requires accurate diagnosis, appropriate emergency management, and correct follow-up treatment.

In the case of dental trauma, all treatment methods are aimed to mitigate undesired complications that may contribute to the loss of the tooth and the loss of the alveolar bone and thereby hinder the realization of a potential treatment plan. It is important to remember that traumatic dental injury care is vital for young people. It is essential to realize that treatment of a traumatic dental injury in a young patient is often complicated, unpredictable, expensive, and can continue for the remainder of his/her life. Since most of traumatic injuries in permanent dentition are between the ages of 10-12 years, dental trauma may have a lifelong effect on the child's quality of life [18]. Therefore, the objective of this systematic review aims to assess the impact of a traumatic dental injury of permanent teeth on oral health-related quality of life and to assess the study quality using the Q-SSP checklist.

\section{Materials and Methods}

The review protocol was registered at PROSPERO (international prospective register of systematic reviews), bearing registration number CRD42021230281.

This review followed the Preferred Reporting Items for Systematic Reviews and MetaAnalyses (PRISMA) statement guidelines [19].

\subsection{Search Strategy}

The following structured question was outlined based on PICO (Patient or problem in question; Intervention of interest; Comparison of intervention; Outcomes): "Does trauma and treatment of traumatic injuries influence the OHRQOL of children and adolescents with a TDI and also how it impacts their family members?".

The electronic search strategy is described in Table 1. A comprehensive electronic search for relevant articles was performed in the following databases: PubMed, Cochrane Library, MEDLINE, and Google Scholar. For all these databases, Boolean operators (OR, AND) were used to combine and narrow down searches that included appropriate $\mathrm{MeSH}$ terms, keywords, and other terms following the syntax rules of each database. All references selected in the search were saved in Mendeley Desktop software to remove the duplicates.

\subsection{Study Selection}

The literature search was limited to articles available in English and to those published between January 2000 and February 2021. Each article was assessed carefully and in detail.

Two independent reviewers (PD and LM) read abstracts and titles, and studies not pertaining to the research question were excluded. The remaining relevant studies' full texts were read and analyzed independently. In this selection, if there was a disagreement of opinions, a third reviewer (DJ) was called to achieve a consensus. 
The selection of studies was performed with no restrictions of place or year of publication. However, the restriction of language was applied, and only those articles written in English language were included. Titles and abstracts were analyzed to determine whether they fulfilled the inclusion criteria: (i) population: healthy children, adolescents, and family members; (ii) exposition: subjects experienced a TDI; (iii) outcome: impact on OHRQoL. The inclusion and exclusion criteria are depicted in Table 2.

Table 1. Search strategy.

\begin{tabular}{c} 
Search Strategy \\
\hline \#1 (Quality of life[MeSH Terms] OR Quality of life[Title/Abstract] OR QoL[Title/Abstract] OR \\
OHRQoL[Title/Abstract] OR Early Childhood Oral Health Impact Scale[Title/Abstract] OR \\
ECOHIS[Title/Abstract] OR Child Perceptions Questionnaire[Title/Abstract] OR CPQ \\
8-10[Title/Abstract] OR CPQ 11-14[Title/Abstract] OR Child-OIDP[Title/Abstract] OR \\
SOHO[Title/Abstract] OR COHIP[Title/Abstract] OR PCPQ[Title/Abstract] OR Scale of Oral \\
Health Outcomes[Title/Abstract] OR Psychology[Title/Abstract] OR Self esteem[Title/Abstract] \\
\hline \#2 (tooth injuries[MeSH Terms] OR tooth injuries[Title/Abstract] OR dental \\
injuries[Title/Abstract] OR dental trauma[Title/Abstract] OR dentoalveolar \\
OR Tooth Luxation[Title/Abstract] OR tooth intrusion[Title/Abstract] OR dental \\
intrusion[Title/Abstract] OR tooth extrusion[Title/Abstract] OR tooth subluxation[Title/Abstract] \\
OR Tooth Fractures[Title/Abstract] OR permanent teeth \\
Final search done:\#1 and \#2 \\
\hline
\end{tabular}

Table 2. Inclusion and exclusion criteria of selecting studies for systematic review.

\begin{tabular}{|c|c|c|}
\hline & Inclusion Criteria & Exclusion Criteria \\
\hline$\bullet$ & $\begin{array}{l}\text { Studies that analyzed TDI in healthy } \\
\text { children and adolescents. }\end{array}$ & $\begin{array}{l}\text { Studies on patients with medical } \\
\text { conditions such as systemic diseases, } \\
\text { syndromes, and craniofacial anomalies. }\end{array}$ \\
\hline$\bullet$ & $\begin{array}{l}\text { Studies that analyzed TDI before and } \\
\text { after treatment of permanent teeth. }\end{array}$ & $\begin{array}{l}\text { - Studies on trauma to deciduous dentition, } \\
\text { or where TDI was excluded and other } \\
\text { oral health issues were addressed. }\end{array}$ \\
\hline$\bullet$ & Studies must have assessed OHRQoL. & $\begin{array}{l}\text { - Studies that evaluated psychometric } \\
\text { properties of instruments of OHRQoL or } \\
\text { studies where only a single question of } \\
\text { the questionnaire was used, evaluating } \\
\text { only one domain. }\end{array}$ \\
\hline$\bullet$ & $\begin{array}{l}\text { Cross-sectional, case control, or } \\
\text { prospective clinical study. }\end{array}$ & $\begin{array}{l}\text { Case reports, review articles, systematic } \\
\text { review articles, and book chapters. }\end{array}$ \\
\hline$\bullet$ & $\begin{array}{l}\text { Studies with abstract and full text in } \\
\text { English language only. }\end{array}$ & \\
\hline
\end{tabular}

Two reviewers (LM and SG) conducted the data extraction and collected the information independently. The relevant data of the included studies were extracted in detail, using Excel spreadsheet (Microsoft, Redmond, WA, USA, Version 2007). The extracted data included: title, journal name, year of publication, type of study, author, country, age group, instrument/application form, TDI index, sample size, tooth number, an association between TDI and OHRQoL, result, conclusion, publication, sample, country where the research was conducted, sample age, comparison, instrument applied, instrument purpose, TDI index, and type of treatment. Mean scores for the OHRQoL instruments (total scale and sub-scales) before and after treatment, $p$-value, and outcome were also identified. 


\subsection{Study Quality Assessment}

The quality of the individual studies was assessed by one reviewer (PD) and independently checked for agreement by a second reviewer (LM). In case of disagreement, a third review author (DJ) was consulted. The quality assessment of the included studies was conducted using the quality assessment checklist for survey studies in psychology (Q-SSP) (Figure 1) [20], published in the year 2020, which includes 20 checklist items. The Q-SSP checklist has been developed to standardize responses to uniform quality assessment across researchers [20]. The quality was judged for each domain and is expressed as a percentage by dividing YES $(\mathrm{Y})$ scores by the total $(\mathrm{T})$ number of APPLICABLE items and multiplying by 100 . When $(T)=20$, then a $Y / T \geq 75 \%$ score may be considered acceptable quality. When $(\mathrm{T})=19$, then a $\mathrm{Y} / \mathrm{T} \geq 73 \%$ score may be considered acceptable quality. When $(\mathrm{T})$ $=18$, then a $\mathrm{Y} / \mathrm{T} \geq 72 \%$ score may be considered acceptable quality. When $(\mathrm{T})=17$, then a $\mathrm{Y} / \mathrm{T} \geq 70 \%$ score may be considered acceptable quality. If the report fails to attain a $\mathrm{Y}$ score for five items, it may be classified as having questionable quality. The assessment was added to an Excel spreadsheet and then imported into ROBVIS (Risk of Bias Visualization web app software).

\begin{tabular}{|c|c|c|}
\hline Item \# & Domain & Item \\
\hline 1 & Introduction & $\begin{array}{l}\text { Was the problem or phenomenon under investigation defined, } \\
\text { described, and justified? }\end{array}$ \\
\hline 2 & Introduction & $\begin{array}{l}\text { Was the population under investigation defined, described, and } \\
\text { justified? }\end{array}$ \\
\hline 3 & Introduction & Were specific research questions or hypotheses stated? \\
\hline 4 & Introduction & Were operational definitions of all study variables provided? \\
\hline 5 & Participants & Were participant inclusion criteria stated? \\
\hline 6 & Participants & Was the participant recruitment strategy described? \\
\hline 7 & Participants & Was a justification/rationale for the sample size provided? \\
\hline 8 & Data & $\begin{array}{l}\text { Was the attrition rate provided? (applies to cross-sectional and } \\
\text { prospective studies) }\end{array}$ \\
\hline 9 & Data & $\begin{array}{l}\text { Was a method of treating attrition provided? (applies to cross- } \\
\text { sectional and prospective studies) }\end{array}$ \\
\hline 10 & Data & $\begin{array}{l}\text { Were the data analysis techniques justified (i.e., was the link } \\
\text { between hypotheses/aims/research questions and data analyses } \\
\text { explained)? }\end{array}$ \\
\hline 11 & Data & $\begin{array}{l}\text { Were the measures provided in the report (or in a supplement) in } \\
\text { full? }\end{array}$ \\
\hline 12 & Data & $\begin{array}{l}\text { Was evidence provided for the validity of all the measures (or } \\
\text { instrument) used? }\end{array}$ \\
\hline 13 & Data & $\begin{array}{l}\text { Was information provided about the person(s) who collected the } \\
\text { data (e.g., training, expertise, other demographic } \\
\text { characteristics)? }\end{array}$ \\
\hline 14 & Data & $\begin{array}{l}\text { Was information provided about the context (e.g., place) of data } \\
\text { collection? }\end{array}$ \\
\hline 15 & Data & $\begin{array}{l}\text { Was information provided about the duration (or start and end } \\
\text { date) of data collection? }\end{array}$ \\
\hline 16 & Data & $\begin{array}{l}\text { Was the study sample described in terms of key demographic } \\
\text { characteristics? }\end{array}$ \\
\hline 17 & Data & $\begin{array}{l}\text { Was discussion of findings confined to the population from which } \\
\text { the sample was drawn? }\end{array}$ \\
\hline 18 & Ethics & Were participants asked to provide (informed) consent or assent? \\
\hline 19 & Ethics & Were participants debriefed at the end of data collection? \\
\hline 20 & Ethics & Were funding sources or conflicts of interest disclosed? \\
\hline
\end{tabular}

Figure 1. Q-SSP checklist for assessing quality of included studies. 


\section{Results}

\subsection{Selection of Studies}

Figure 2 presents a flowchart of the systematic review process. The search in the selected databases allowed for the identification of 2677 articles. After removing duplicates, 2350 searches remained. Of these, 2297 were excluded after reading the titles and abstracts. From 53 remaining articles, 25 articles were finally selected after reading the full texts. Table A1 in Appendix A presents a list of the studies excluded after reading the full texts and the justification.

Identification

Records identified in the search database

$(n=2677)$

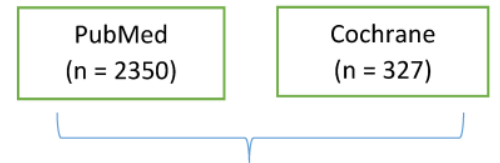

Selection

Duplicates removed $(n=325)$

Eligibility

Articles in full document text evaluated for eligibility $(n=50)$

Inclusion

Studies included to evaluate the oral health related quality of life $(n=25)$

Figure 2. PRISMA 2020 flow diagram for systematic review that includes searches of databases.

\subsection{Characteristics of Studies}

Most of the studies were cross-sectional [9,15,20-30], six studies were case control [31-36], and three studies were prospective clinical studies [37-39].

Nine studies [15,21,24,25,29,31-33,35] evaluated patients with TDI and no TDI, whereas eight studies [9,26,37-42] evaluated patients with TDI and after TDI treatment. One study [43] compared TDI and TDI with treatment needs. Another study [27] compared no TDI with TDI or without treatment needs. One study [22] evaluated TDI with no oral condition and TDI associated with dental caries, one study [23] evaluated mild/no TDI with severe TDI, one compared TDI with no treatment and TDI followed by treatment, two studies [28,30] evaluated patients with trauma, and one study [34] evaluated patients with TDI with unmet treatment needs and without TDI.

The included studies used different instruments to assess the OHRQoL (Table 3). From 25 included studies, the most widely used instrument for assessing OHRQoL of permanent teeth was the Child Perceptions Questionnaire (CPQ) $(n=15)$. The form of application most used was self-administered $(n=22)$. The Oral Impact on Daily Performances (OIDP) was used in five articles. The Family Impact Scale (FIS) was used in three articles, the 
Parental-Caregivers Perceptions Questionnaire (P-CPQ) in three articles, and the Oral Health Impact Profile (OHIP) in one study. One study used the National Research in Oral health (SBBrasil2010). Andreasen proposed the index for the TDI registry used by 15 articles. Seven articles used O' Brien, one article used the Dental Trauma Index (DTI), and two articles used WHO 1997 for TDI registry. Regarding TDI association and impact on OHRQoL, 24 articles indicated an association, whereas one article indicated no association.

\subsection{Analysis of Quality of the Studies}

Risk of bias in included studies is presented in Figures 3 and 4 . Out of the 25 included articles, 21 articles are of acceptable quality scoring $\geq 75 \%$, whereas 4 articles are of questionable quality with a score of $<75 \%$.

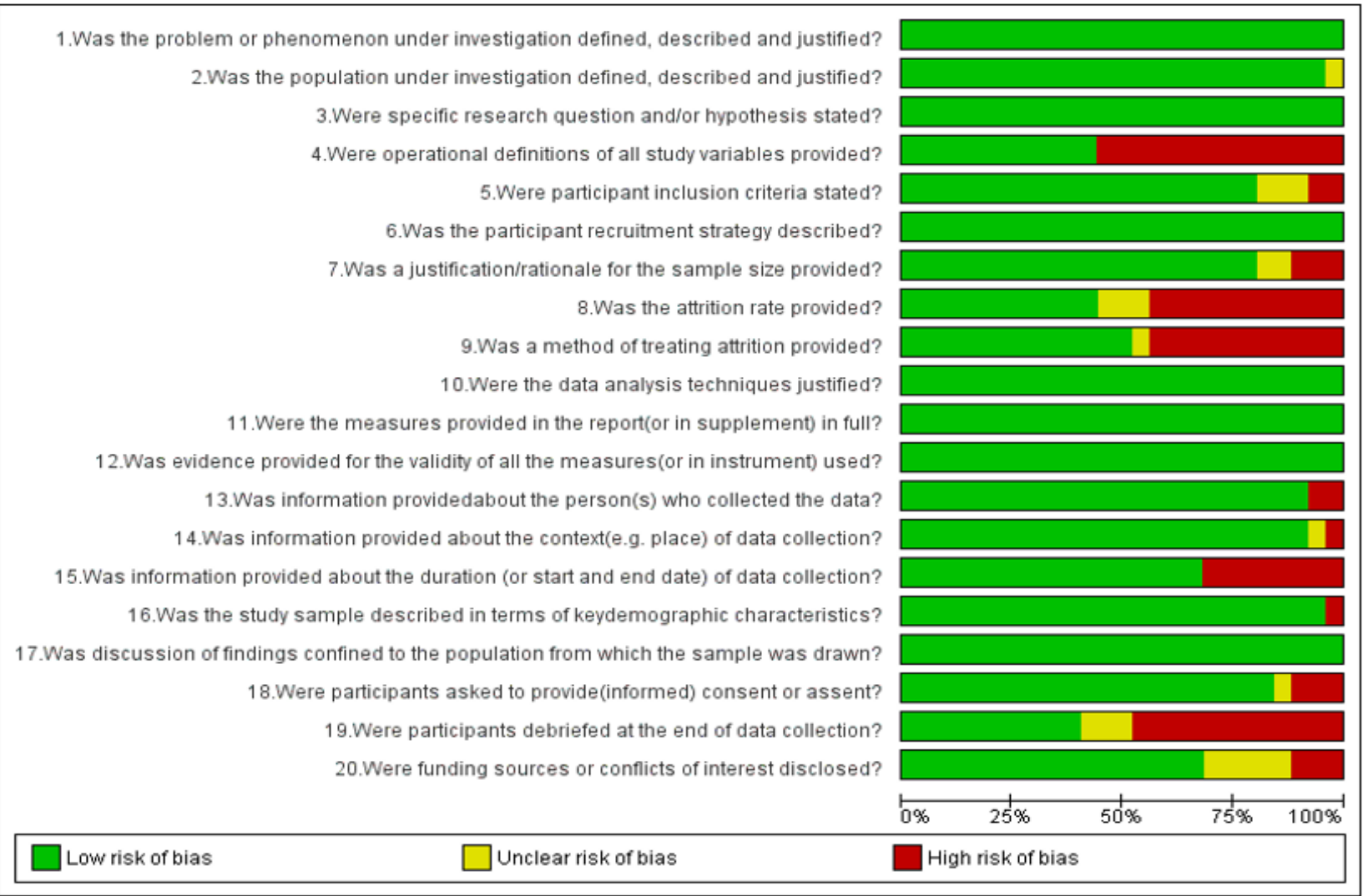

Figure 3. Quality assessment of studies using a QSSP tool graph: review authors' judgements about each risk of bias item presented as percentages across all included studies.

\subsection{Synthesis of Results}

Due to a high heterogeneity of the data, it was not possible to perform a meta-analysis for all the parameters used in the included studies; therefore, a qualitative assessment was performed. Table 4 shows the value of each domain and its impact on OHRQoL. 
Table 3. Data extraction of included studies.

\begin{tabular}{|c|c|c|c|c|c|c|c|}
\hline Author/Year & $\begin{array}{l}\text { Population } \\
\text { Investigated }\end{array}$ & Age Group & Instrument & TDI Index & $\begin{array}{c}\text { Association } \\
\text { of TDI and } \\
\text { OHRQoL }\end{array}$ & Conclusions & Funding \\
\hline $\begin{array}{l}\text { Diaz et al. } \\
\text { (2018) [21] }\end{array}$ & Colombia & 6-14 years & $\begin{array}{c}\text { P-CPQ } \\
\text { of } \\
\text { COHRQoL }\end{array}$ & Andreasen & No & $\begin{array}{l}\text { Children who studied at public schools were more likely to } \\
\text { experience a negative impact on the emotional wellbeing and } \\
\text { social wellbeing domains. There was no association between } \\
\text { traumatic dental injuries and the perception of the impact of } \\
\text { OHRQoL, but this may be due to the low prevalence of TDI in } \\
\text { the sample. }\end{array}$ & None. \\
\hline $\begin{array}{l}\text { Antunes et al. } \\
\text { (2012) [37] }\end{array}$ & Brazil & $8-14$ years & $\begin{array}{c}\text { P-CPQ } \\
\text { Brazilian } \\
\text { version }\end{array}$ & Andreasen & Yes & $\begin{array}{l}\text { The tooth most affected was the right maxillary central incisor } \\
(41.2 \%) \text {. The type of tissue most injured was dental tissue ( } 54.8 \%) \text {. } \\
\text { The most prevalent type of TDI was fracture of enamel and dentin } \\
(48.9 \%) \text {. It could be observed that the highest levels of impact and } \\
\text { its reduction after treatment were in the group of trauma affecting } \\
\text { both dental and support tissue. However, noticeable change over } \\
\text { time could be identified (positive reduction) for all types of TDI, } \\
\text { which denotes } 100 \% \text { of the population benefitting from } \\
\text { trauma treatment. }\end{array}$ & $\begin{array}{l}\text { DAB/SAS/MS (Department of Primary } \\
\text { Care/Secretary of Health Care/Ministry of } \\
\text { Health), DECIT/SCTIE/MS (Department of } \\
\text { Science and Technology/Secretary of Science, } \\
\text { Technology and Strategic } \\
\text { Resources/Ministry of Health)—CNPq (The } \\
\text { National Council for Scientific and } \\
\text { Technological Development) and FAPERJ. }\end{array}$ \\
\hline $\begin{array}{l}\text { Magno et al. } \\
\text { (2019) [38] }\end{array}$ & Brazil & $8-14$ years & $\begin{array}{l}\text { CPQ8-10, } \\
\text { CPQ11-14, } \\
\text { P-CPQ, FIS }\end{array}$ & Andreasen & Yes & $\begin{array}{l}\text { In general, children (aged 8-10 years) and adolescents (aged } \\
10-14 \text { years) presented with a reduction of the negative impact of } \\
\text { OHRQoL following restorative treatment of CFED; however, the } \\
\text { completion of the same treatment did not affect the OHRQoL of } \\
\text { their families. }\end{array}$ & $\begin{array}{l}\text { Coordenacao de Aperfeicoamnto de } \\
\text { Pessoal de. }\end{array}$ \\
\hline $\begin{array}{l}\text { Berger et al. } \\
(2009)[40]\end{array}$ & Canada & $8-20$ years & $\begin{array}{l}\text { CPQ8-10, } \\
\text { CPQ11-14, } \\
\text { PPQ and FIS }\end{array}$ & & Yes & $\begin{array}{l}\text { Children and adolescents who sustain a dental injury severe } \\
\text { enough to warrant splinting of the maxillary anterior teeth suffer } \\
\text { an immediate decrease in their QoL. Results indicated that at one } \\
\text { year, children are affected mostly in the emotional or social } \\
\text { well-being domains, yet their parents exclusively reported } \\
\text { one-year effects that were based on oral symptoms and functional } \\
\text { limitations. Results from the emotional well-being component of } \\
\text { the COHQoL questionnaire indicate that dental trauma continues } \\
\text { to cause emotional distress and financial difficulties for the } \\
\text { injured child and their parent one year later. }\end{array}$ & $\begin{array}{l}\text { Dentistry Clinical Research Fund: Rhani } \\
\text { Ghar Grotto Endowment. }\end{array}$ \\
\hline $\begin{array}{l}\text { Martins et al. } \\
(2018)[22]\end{array}$ & Brazil & $8-10$ years & CPQ8-10 & Andreasen & Yes & $\begin{array}{l}\text { Children who presented with dental caries associated with TDI, } \\
\text { as well as dental caries associated with malocclusion, were more } \\
\text { likely to experience a high negative impact on their OHRQoL } \\
\text { than those without any oral condition. Children with the three } \\
\text { oral conditions were } 2.01 \text {-fold more likely to experience a high } \\
\text { negative impact on their OHRQoL (total score) than those } \\
\text { without any oral health problems. }\end{array}$ & Not stated. \\
\hline
\end{tabular}


Table 3. Cont.

\begin{tabular}{|c|c|c|c|c|c|c|c|}
\hline Author/Year & $\begin{array}{l}\text { Population } \\
\text { Investigated }\end{array}$ & Age Group & Instrument & TDI Index & $\begin{array}{c}\text { Association } \\
\text { of TDI and } \\
\text { OHRQoL }\end{array}$ & Conclusions & Funding \\
\hline $\begin{array}{c}\text { Sardenberg } \\
\text { et al. } \\
\text { (2017) [24] }\end{array}$ & Brazil & $8-10$ years & CPQ8-10 & Andreasen & Yes & $\begin{array}{l}\text { The mean CPQ8-10 score was } 1.38 \text {-fold (95\% CI: } 1.17-1.63 \text {; } \\
p<0.001) \text { higher among the girls than boys, and children from } \\
\text { families with a higher income had lower CPQ8-10 scores (RR: } \\
0.67,95 \% \text { CI: } 0.51-0.88 ; p<0.004) \text { than those from families with a } \\
\text { lower income. Children who sought dental care due to pain or } \\
\text { factors other than prevention, those with orofacial dysfunction, } \\
\text { and those with a history of TDI also experienced a greater impact } \\
\text { on OHRQoL. }\end{array}$ & $\begin{array}{l}\text { Conselho Nacional de Desenvolvimento } \\
\text { Científico e Tecnológico and Coordenação de } \\
\text { Aperfeiçoamento de Pessoal de } \\
\text { Nível Superior. }\end{array}$ \\
\hline $\begin{array}{l}\text { Freire-Maia } \\
\text { et al. } \\
\text { (2015) [23] }\end{array}$ & Brazil & $8-10$ years & $\begin{array}{c}\text { CPQ8-10 } \\
\text { Brazilian } \\
\text { version }\end{array}$ & Andreasen & Yes & $\begin{array}{l}\text { Girls had a 1.46-fold greater chance of presenting a high negative } \\
\text { impact on OHRQoL and younger children had more chance of a } \\
\text { high negative impact. Children with severe dental trauma ( } 55.9 \%) \\
\text { reported more negative impact on OHRQoL than children with } \\
\text { dental caries }(44.4 \%) \text { and/or accentuated anterior maxillary } \\
\text { overjet }(41.1 \%) \text {. }\end{array}$ & $\begin{array}{l}\text { National Council for Scientific and } \\
\text { Technological Development (CNPq), the } \\
\text { Ministry of Science and Technology, and the } \\
\text { State of Minas Gerais Research Foundation } \\
\text { (FAPEMIG), Brazilian Coordination of } \\
\text { Higher Education (CAPES), Brazil. }\end{array}$ \\
\hline $\begin{array}{c}\text { Silva- } \\
\text { Oliveira et al. } \\
\text { (2018) [25] }\end{array}$ & Brazil & 12 years & $\begin{array}{l}\text { CPQ11-14- } \\
\text { ISF:16 short } \\
\text { form }\end{array}$ & Andreasen & Yes & $\begin{array}{l}\text { The central incisors were the most affected teeth. TDI was } \\
\text { associated with an overjet equal to or greater than } 3 \mathrm{~mm} \text {. There } \\
\text { was also an association of the negative impact on oral } \\
\text { health-related quality of life, among patients who presented with } \\
\text { TDI, in the social well-being and emotional well-being subscales. } \\
\text { No association between TDI and socioeconomic factors } \\
\text { was observed. }\end{array}$ & Not stated. \\
\hline $\begin{array}{l}\text { Rajab et al. } \\
\text { (2019) [26] }\end{array}$ & Jordan & 12 years & $\begin{array}{c}\text { CPQ11-14 } \\
\text { Arabic } \\
\text { version }\end{array}$ & Andreasen & Yes & $\begin{array}{l}\text { When each of the } 16 \text { items of the CPQ11-14 was considered, } \\
\text { higher impacts were reported by children who had untreated TDI. } \\
\text { The mean scores of the } 16 \text { items of the CPQ11-14 were higher in } \\
\text { the group of untreated TDI than those in both the group treated } \\
\text { TDI and the group with absence of trauma. The results of the } \\
\text { present study confirm the negative impact of untreated TDI on } \\
\text { QoL of schoolchildren. }\end{array}$ & Not stated. \\
\hline $\begin{array}{l}\text { Bendo et al. } \\
\text { (2010) [15] }\end{array}$ & Brazil & $11-14$ years & $\begin{array}{c}\text { CPQ11-14 } \\
\text { Brazilian } \\
\text { version }\end{array}$ & Andreasen & Yes & $\begin{array}{l}\text { Children with untreated TDI were } 1.2-\text { fold }(95 \% \mathrm{CI}=0.9-1.6) \\
\text { more likely to feel "upset" and } 1.2-\text { fold }(95 \% \mathrm{CI}=0.9-1.7) \text { more } \\
\text { likely to have "avoided smiling / laughing" than children without } \\
\text { TDI. In the comparison of children with treated fractures and } \\
\text { those without TDI, there was no association to the overall } \\
\text { CPQ11-14-ISF: } 16 \text { score (Fisher }=0.610) \text {. Dental pain and } \\
\text { difficulty chewing were more prevalent among children with } \\
\text { treated teeth than those with no TDI, but this difference did not } \\
\text { achieve statistical significance }(p>0.05) \text {. }\end{array}$ & $\begin{array}{l}\text { National Council for Scientific and } \\
\text { Technological Development (CNPq), } \\
\text { Ministry of Science and Technology, and the } \\
\text { State of Minas Gerais Research Foundation } \\
\text { (FAPEMIG), Brazil. }\end{array}$ \\
\hline
\end{tabular}


Table 3. Cont.

\begin{tabular}{|c|c|c|c|c|c|c|c|}
\hline Author/Year & $\begin{array}{l}\text { Population } \\
\text { Investigated }\end{array}$ & Age Group & Instrument & TDI Index & $\begin{array}{l}\text { Association } \\
\text { of TDI and } \\
\text { OHRQoL }\end{array}$ & Conclusions & Funding \\
\hline $\begin{array}{l}\text { Bendo et al. } \\
\text { (2014) (1) [31] }\end{array}$ & Brazil & $11-14$ years & $\begin{array}{l}\text { CPQ11-14 } \\
\text { Brazilian } \\
\text { version }\end{array}$ & Andreasen & Yes & $\begin{array}{l}\text { Age was not associated with impact on adolescents' OHRQoL. } \\
\text { However, adolescents diagnosed with fractures involving dentin } \\
\text { and/or pulp, untreated dental caries, and malocclusion had a } \\
\text { greater chance of presenting high negative impact on OHRQoL. } \\
\text { The results demonstrated that adolescents diagnosed with } \\
\text { fractures involving dentin and/or pulp had a 2.40-fold greater } \\
\text { chance of presenting high negative impact on QHRQoL than } \\
\text { those without evidence of TDI. }\end{array}$ & $\begin{array}{l}\text { Coordination for the Improvement of } \\
\text { Higher-Level Education Personnel (CAPES), } \\
\text { the National Council for Scientific and } \\
\text { Technological Development (CNPq), and the } \\
\text { State of Minas Gerais Research Foundation } \\
\text { (FAPEMIG), Brazil. }\end{array}$ \\
\hline $\begin{array}{l}\text { Porrit et al. } \\
\text { (2011) [41] }\end{array}$ & UK & $7-17$ years & $\begin{array}{l}\text { CPQ11-14- } \\
\text { ISF:16 } \\
\text { short form }\end{array}$ & Andreasen & Yes & $\begin{array}{l}\text { The results revealed that girls were more likely to report a higher } \\
\text { level of impact on their OHRQoL and HRQoL than boys } \\
\text { following traumatic injury to their permanent incisors. }\end{array}$ & Not stated. \\
\hline $\begin{array}{l}\text { Traebert et al. } \\
\text { (2012) [43] }\end{array}$ & Brazil & $11-14$ years & $\begin{array}{l}\text { CPQ11-14- } \\
\text { ISF:16 } \\
\text { short form }\end{array}$ & O’Brien & Yes & $\begin{array}{l}\text { Enamel fractures were the most common form of TDI, while } \\
\text { adhesive restoration was the most common form of treatment } \\
\text { needed for TDI. This study showed a statistically significant and } \\
\text { independent association between TDI and OHRQoL among } \\
\text { Brazilian 11-14-year-old schoolchildren. }\end{array}$ & Grant from FAPESC - Fundacao de Apoio a. \\
\hline $\begin{array}{l}\text { Dame- } \\
\text { Texeira et al. } \\
(2013)[27]\end{array}$ & Brazil & 12 years & $\begin{array}{l}\text { CPQ11-14- } \\
\text { ISF:16 } \\
\text { short form }\end{array}$ & O’Brien & No & $\begin{array}{l}\text { Individuals presenting TDI with treatment needs experienced a } \\
\text { higher average CPQ11-14 score than individuals with no TDI or } \\
\text { with TDI without treatment needs. The main finding was that } \\
\text { schoolchildren affected by TDI and needing clinical intervention } \\
\text { had significantly higher adjusted mean CPQ11-14 scores for } \\
\text { function impairment than those with no TDI or affected by TDI } \\
\text { with no treatment needs, indicating a significant but limited effect } \\
\text { on quality of life. Where no overall association was observed } \\
\text { between TDI and OHRQoL, a domain-specific analysis revealed } \\
\text { significant association between TDI and function impairment. } \\
\text { Schoolchildren presenting with TDI with clinical treatment needs } \\
\text { (e.g., restorations, crowns, root canal therapy) had a 1.2-fold } \\
\text { higher adjusted mean CPQ11-14 score than the reference group } \\
\text { (no TDI/no treatment needs). }\end{array}$ & None. \\
\hline $\begin{array}{l}\text { Antunes et al. } \\
\text { (2013) [32] }\end{array}$ & Brazil & $10-15 y$ & $\begin{array}{l}\text { CPQ11-14- } \\
\text { ISF:16 } \\
\text { short form }\end{array}$ & WHO 1997 & Yes & $\begin{array}{l}\text { Children and adolescents with traumatic dental injury were more } \\
\text { likely to have a greater impact on their life than those with no } \\
\text { injuries. Traumatic dental injury actually affects the quality-of-life } \\
\text { of children and adolescents and, consequently, it is not enough to } \\
\text { treat only its signs and physical symptoms. In fact, oral } \\
\text { symptoms but also functional limitations and emotional and } \\
\text { social well-being should be considered. }\end{array}$ & Not stated. \\
\hline
\end{tabular}


Table 3. Cont.

\begin{tabular}{|c|c|c|c|c|c|c|c|}
\hline Author/Year & $\begin{array}{l}\text { Population } \\
\text { Investigated }\end{array}$ & Age Group & Instrument & TDI Index & $\begin{array}{c}\text { Association } \\
\text { of TDI and } \\
\text { OHRQoL }\end{array}$ & Conclusions & Funding \\
\hline $\begin{array}{l}\text { Locker et al. } \\
\text { (2007) [42] }\end{array}$ & Canada & $\begin{array}{l}11 / 12 \text { years } \\
13 / 14 \text { years }\end{array}$ & $\begin{array}{c}\text { CPQ11-14- } \\
10 \text { short } \\
\text { form }\end{array}$ & $\begin{array}{c}\text { Dental } \\
\text { Trauma Index }\end{array}$ & Yes & $\begin{array}{l}\text { Over one third, } 37.5 \% \text {, showed evidence of injury to the anterior } \\
\text { dentition (DTI codes of 1-5), with } 15.3 \% \text { having one or more teeth } \\
\text { with severe injury (DTI codes of 2-5). Children from low-income } \\
\text { households had higher scores on a short form of the CPQ11-14 } \\
\text { than children from high-income households, indicating poorer } \\
\text { oral health-related quality of life. }\end{array}$ & Grant from the Ontario Ministry of Health. \\
\hline $\begin{array}{c}\text { Fakhruddin } \\
\text { et al. } \\
\text { (2008) [33] }\end{array}$ & Canada & $12-14$ years & $\begin{array}{c}\text { CPQ11-14- } \\
10 \text { short } \\
\text { form }\end{array}$ & $\begin{array}{c}\text { Dental } \\
\text { Trauma Index }\end{array}$ & Yes & $\begin{array}{l}\text { Children with untreated dental injuries were approximately three } \\
\text { times more likely to report difficulty chewing than those without } \\
\text { injury. Subjects with untreated dental trauma were approximately } \\
\text { three times more likely to avoid smiling or laughing and four } \\
\text { times more likely to report not wanting to talk to other children } \\
\text { compared with uninjured controls. The impact of dental trauma } \\
\text { to upper incisors on social well-being was greater than on } \\
\text { functional and psychological well-being in this sample of } \\
\text { 12-14-year-old schoolchildren. Those with untreated dental } \\
\text { injuries experienced a higher risk of negative social impact on } \\
\text { their daily living than those without injury. }\end{array}$ & Grant from the Ontario Ministry of Health. \\
\hline $\begin{array}{l}\text { Bendo et al. } \\
\text { (2014) (2) [29] }\end{array}$ & Brazil & $11-14$ years & $\begin{array}{c}\text { FIS } \\
\text { Brazilian } \\
\text { version }\end{array}$ & Andreasen & Yes & $\begin{array}{l}\text { TDI severity was directly associated with an impact on the family's } \\
\text { QoL, especially regarding parental/family activities. } \\
\text { Parents/caregivers of adolescents with fractures involving the dentine } \\
\text { or dentine/pulp reported more negative impact on parental/family } \\
\text { activities than those with less severe TDI, such as enamel fracture. }\end{array}$ & $\begin{array}{l}\text { Coordination for the Improvement of } \\
\text { Higher-Level Education Personnel (CAPES), } \\
\text { Ministry of Education, and the State of } \\
\text { Minas Gerais Research Foundation } \\
\text { (FAPEMIG), Brazil. }\end{array}$ \\
\hline $\begin{array}{l}\text { Gianenetti } \\
\text { et al. } \\
\text { (2007) [39] }\end{array}$ & Italy & $\begin{array}{l}\text { Under } 18 \\
\text { years }\end{array}$ & OHIP-14 & Andreasen & Yes & $\begin{array}{l}\text { It was a single tooth avulsed in } 63.3 \% \text { of the population, } 49.5 \% \\
\text { was central incisor. Adverse impacts on OHRQoL were reported } \\
\text { much more frequently among patients who got into failure of } \\
\text { replantation compared with patients who got into successful } \\
\text { replantation. The findings show that if patients got into tooth } \\
\text { avulsion, then their quality of life is adversely affected. }\end{array}$ & Not stated. \\
\hline $\begin{array}{l}\text { Bomfim et al. } \\
\text { (2017) [30] }\end{array}$ & Brazil & 12 years & $\begin{array}{l}\text { National } \\
\text { Research in } \\
\text { Oral Health } \\
\quad \text { (SB- } \\
\text { Brasil2010) }\end{array}$ & & Yes & $\begin{array}{l}\text { Regarding occlusal characteristics, crowding in at least one } \\
\text { segment was associated with trauma in the maxillary teeth and in } \\
\text { mandibular teeth. Crowding in two segments increased the chances } \\
\text { of fracture. The spacing/diastema between the arches was a risk } \\
\text { factor for enamel fractures, fractures in mandibular teeth, and for } \\
\text { any fracture analyzed. The presence of a diastema and mandibular } \\
\text { overjet was not associated with any type of TDI. Maxillary overjet } \\
\text { (greater than } 3 \mathrm{~mm} \text { ) was associated with all fractures in maxillary } \\
\text { teeth. Anterior open bite was a protective factor for enamel } \\
\text { fractures in maxillary teeth and any analyzed TDI. }\end{array}$ & Not stated. \\
\hline
\end{tabular}


Table 3. Cont.

\begin{tabular}{|c|c|c|c|c|c|c|c|}
\hline Author/Year & $\begin{array}{l}\text { Population } \\
\text { Investigated }\end{array}$ & Age Group & Instrument & TDI Index & $\begin{array}{l}\text { Association } \\
\text { of TDI and } \\
\text { OHRQoL }\end{array}$ & Conclusions & Funding \\
\hline $\begin{array}{l}\text { Ramos-Jorge } \\
\text { et al. } \\
\text { (2014) [9] }\end{array}$ & Brazil & $11-14$ years & Child-OIDP & $\mathrm{O}^{\prime}$ Brien & Yes & $\begin{array}{l}\text { Schoolchildren with untreated TDI experienced a greater negative } \\
\text { impact on quality of life in comparison with those without TDI. } \\
\text { This impact was significant regarding eating and smiling. No } \\
\text { significant differences were found on the Child-OIDP between } \\
\text { schoolchildren with treated TDI and those without TDI. The } \\
\text { association between untreated TDI and impact on quality of life in } \\
\text { the present study was stronger for 'eating and enjoying food' and } \\
\text { 'smiling and showing teeth'. }\end{array}$ & $\begin{array}{l}\text { Brazilian fostering agencies the Coordination } \\
\text { of Higher Education (CAPES), Ministry of } \\
\text { Education, and the State of Minas Gerais } \\
\text { Research Foundation (FAPEMIG). }\end{array}$ \\
\hline $\begin{array}{l}\text { Thelen et al. } \\
\text { (2011) [34] }\end{array}$ & Albania & $16-19$ years & OIDP & O'Brien & Yes & $\begin{array}{l}\text { The overall impact prevalence of OIDP among cases was } \\
\text { significantly higher ( } 88.4 \% \text { ) than for the controls ( } 58.9 \% \text { ). The } \\
\text { most prevalent impact was 'smiling and showing teeth without } \\
\text { embarrassment' which was reported by cases } 78.9 \% \text { and their } \\
\text { controls } 31.6 \% \text {. The second-most prevalent impact was 'enjoying } \\
\text { contact with people'. } \\
\text { TDI with unmet treatment needs in this sample of adolescents are } \\
\text { associated with reduced OHRQoL. Compared to adolescents with } \\
\text { no history of TDI, those affected by TDI with unmet treatment } \\
\text { needs are at greater risk of suffering impacts on OHRQoL in the } \\
\text { form of OIDP. }\end{array}$ & $\begin{array}{l}\text { Department of Clinical Dentistry and the } \\
\text { Centre for International Health, University } \\
\text { of Bergen. }\end{array}$ \\
\hline $\begin{array}{l}\text { Basavaraj } \\
\text { et al. } \\
\text { (2014) [28] }\end{array}$ & India & $\begin{array}{c}12 \text { and } 15 \\
\text { years }\end{array}$ & Child-OIDP & WHO & Yes & $\begin{array}{l}\text { Impacts on eating were the most prevalent }(45.3 \%) \text {. The } \\
\text { prevalence of impacts on cleaning teeth }(42.3 \%) \text { and smiling } \\
(40.1 \%) \text { were also relatively high. There is a strong association } \\
\text { between clinical dental indicators and oral impacts in children. }\end{array}$ & None. \\
\hline $\begin{array}{l}\text { Cortes et al. } \\
(2002)[35]\end{array}$ & Brazil & $12-14$ years & OIDP & O'Brien & Yes & $\begin{array}{l}\text { The prevalence of oral impacts, measured by the OIDP index, was } \\
\text { higher for children with untreated fractured teeth than for } \\
\text { children with non-fractured teeth. For both groups of children, } \\
\text { the most prevalent OIDP impact was 'smiling, laughing, and } \\
\text { showing teeth without embarrassment', with the proportion } \\
\text { being higher for cases }(55.9 \%) \text { than for controls }(13.2 \%) \text {. }\end{array}$ & $\begin{array}{l}\text { Grant from Conselho Nacional de Pesquisa } \\
\text { (CNPq). }\end{array}$ \\
\hline
\end{tabular}


Table 3. Cont.

\begin{tabular}{|c|c|c|c|c|c|c|c|}
\hline Author/Year & $\begin{array}{l}\text { Population } \\
\text { Investigated }\end{array}$ & Age Group & Instrument & TDI Index & $\begin{array}{c}\text { Association } \\
\text { of TDI and } \\
\text { OHRQoL }\end{array}$ & Conclusions & Funding \\
\hline $\begin{array}{c}\text { Ramos-Jorge } \\
\text { et al. } \\
\text { (2007) [36] }\end{array}$ & Brazil & $12-14$ years & OIDP & $\mathrm{O}^{\prime}$ Brien & Yes & $\begin{array}{l}\text { The impact prevalence was greater in the case group for nearly all } \\
\text { the appraised activities. } \\
\text { In the previous six months, } 40 \% \text { of the teenagers with a history of } \\
\text { treatment for enamel dentin fractures had at least one negatively } \\
\text { affected daily activity, and } 16.9 \% \text { of the teenagers without a history } \\
\text { of trauma were found to have some oral impact on their daily lives. } \\
\text { The most affected activities in decreasing order were showing teeth } \\
\text { when smiling, eating, speaking, maintaining a stable emotional } \\
\text { state, and cleaning the mouth. Sleeping, doing school tasks, } \\
\text { practicing sports, and going out with friends were all mentioned as } \\
\text { activities that no adolescent reported as having an impact. } \\
\text { Adolescents with aesthetically-treated enamel dentin fractures were } \\
\text { more likely than those who had never experienced dental trauma to } \\
\text { present oral impact on daily activities. Treatment for coronary } \\
\text { fractures does not completely eradicate the impact of trauma on the } \\
\text { adolescents daily lives, but it does help to mitigate it. }\end{array}$ & Not stated. \\
\hline
\end{tabular}

Legend: OHRQoL—oral health-related quality of life; P-CPQ—Parental-Caregiver Perception Questionnaire; CPQ—Child Perceptions Questionnaire; FIS—Family Impact Scale CFED—crown fracture involving enamel and dentin; OHIP—Oral Health Impact Profile; COHQoL—Child Oral Health Quality of Life; ISF—Impact Short Form; DTI—Dental Trauma Index; Child-OIDP—Child-Oral Impacts on Daily Performances; OIDP—Oral Impact on Daily Performances. 


\begin{tabular}{|c|c|c|c|c|c|c|c|c|c|c|c|c|c|c|c|c|c|c|c|c|}
\hline & 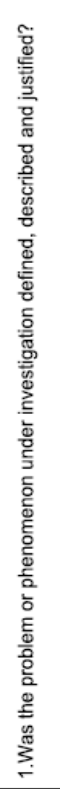 & 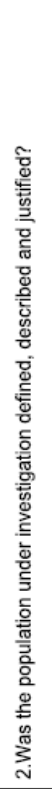 & 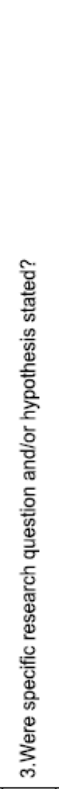 & 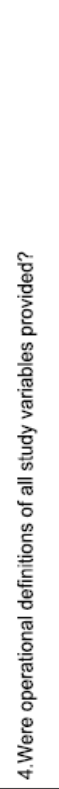 & 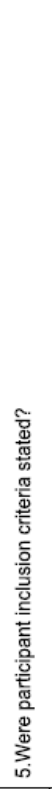 & 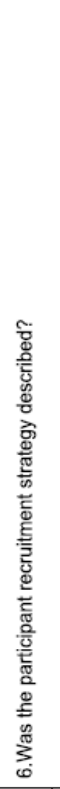 & 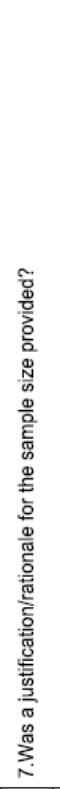 & 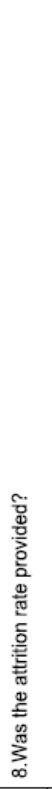 & 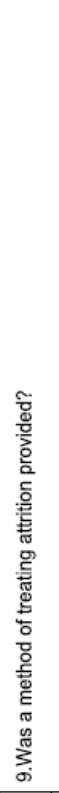 & 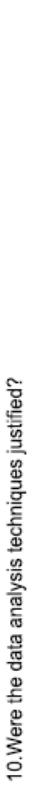 & 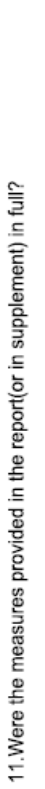 & 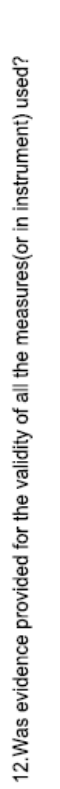 & 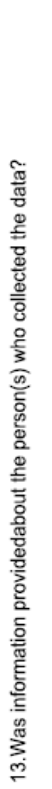 & 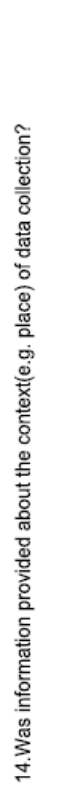 & 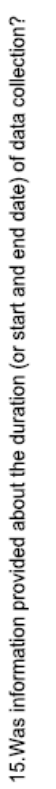 & 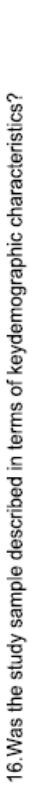 & 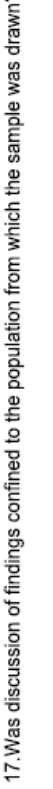 & 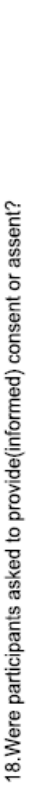 & & 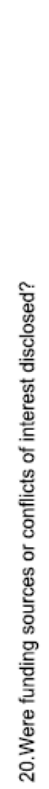 \\
\hline Antunes 2012 & $\odot$ & ๑ & $\odot$ & $\odot$ & $\odot$ & $\odot$ & - & ๑ & $\odot$ & ๑ & ๑ & ๑ & $\odot$ & ? & ๑ & $\odot$ & † & † & అ & + \\
\hline Antunes 2013 & $\odot$ & ๑ & + & $\odot$ & 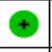 & + & $?$ & 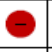 & $\theta$ & ๑ & ๑ & ๑ & ๑ & + & $\ominus$ & $\oplus$ & $\oplus$ & 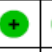 & $\rightarrow$ & + \\
\hline Basavaraj 2014 & + & + & + & + & + & + & + & $\theta$ & $\theta$ & $\oplus$ & $\oplus$ & + & + & 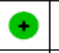 & ๑ & + & + & + & $?$ & + \\
\hline Bendo 2010 & $\odot$ & $\odot$ & $\odot$ & $\theta$ & $\odot$ & $\odot$ & ๑ & $?$ & $\odot$ & ๑ & ๑ & $\oplus$ & ๑ & ๑ & ๑ & $\odot$ & 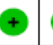 & 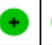 & $\oplus$ & $\odot$ \\
\hline Bendo 2014 (1) & $\odot$ & ๑ & $\odot$ & $\odot$ & ? & $\odot$ & $\odot$ & అ & $\theta$ & ๑ & $\odot$ & $\oplus$ & $\odot$ & ๑ & అ & $\odot$ & 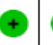 & 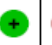 & $\theta$ & $?$ \\
\hline Bendo 2014 (2) & $\odot$ & ๑ & 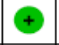 & $\odot$ & $\odot$ & $\odot$ & $\odot$ & ๑ & $\odot$ & ๑ & ๑ & ๑ & ๑ & ๑ & ๑ & ๑ & + & † & ๑ & 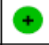 \\
\hline Berger 2009 & $\odot$ & ๑ & $\odot$ & అ & ๑ & $\odot$ & ๑ & ๑ & $\odot$ & ๑ & ๑ & $\oplus$ & $\oplus$ & ๑ & $\oplus$ & ๑ & 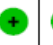 & 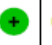 & $?$ & $?$ \\
\hline Cortes 2002 & $\odot$ & $\odot$ & $\odot$ & $\theta$ & $\odot$ & $\odot$ & $\oplus$ & $\odot$ & $\odot$ & $\oplus$ & $\odot$ & $\odot$ & $\oplus$ & 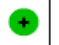 & $\theta$ & $\odot$ & $\odot$ & అ & $\boldsymbol{\theta}$ & $\odot$ \\
\hline Diaz 2018 & $\odot$ & ๑ & + & అ & $\odot$ & + & $\odot$ & ๑ & + & † & $\oplus$ & ๑ & + & + & ๑ & • & + & † & $\oplus$ & $\odot$ \\
\hline Fakhruddin 2008 & $\odot$ & ๑ & ๑ & 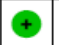 & ๑ & $\odot$ & 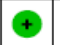 & అ & $\theta$ & ๑ & $\odot$ & ๑ & ๑ & ๑ & అ & $\odot$ & + & + & 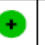 & 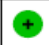 \\
\hline Freire-Maia 2015 & $\odot$ & ๑ & $\odot$ & $\odot$ & ๑ & $\odot$ & $\odot$ & ๑ & $\odot$ & ๑ & ๑ & ๑ & ๑ & ๑ & $\oplus$ & ๑ & $\oplus$ & † & అ & 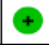 \\
\hline Giannetti 2007 & $\odot$ & $?$ & $\odot$ & 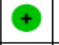 & అ & $\odot$ & - & - & ○ & ๑ & ๑) & ๑ & - & - & - & ○ & 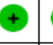 & † & అ & $\theta$ \\
\hline Locker 2007 & $\odot$ & ๑ & $\odot$ & - & $\oplus$ & $\odot$ & ? & అ & - & ๑ & ๑ & $\oplus$ & $\odot$ & 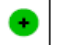 & $\odot$ & $\odot$ & $\oplus$ & $?$ & $\oplus$ & $\oplus$ \\
\hline Magno 2019 & $\odot$ & 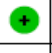 & $\odot$ & $\odot$ & $\odot$ & + & $\odot$ & $\odot$ & $\odot$ & † & † & ๑ & + & $\odot$ & † & ๑ & $\oplus$ & $\theta$ & $\theta$ & + \\
\hline Martins 2018 & $\odot$ & + & + & $\theta$ & $\boldsymbol{\theta}$ & + & $\odot$ & $\odot$ & $?$ & ๑ & 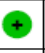 & + & $\odot$ & † & - & 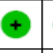 & + & + & $\theta$ & $?$ \\
\hline Porritt 2011 & $\odot$ & ๑) & $\odot$ & - & $\odot$ & $\odot$ & ๑ & $\odot$ & - & ๑ & ๑ & ๑ & అ & 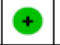 & - & $\odot$ & $\oplus$ & + & 3 & $\theta$ \\
\hline Rafael 2017 & $\odot$ & $\odot$ & $\odot$ & $\theta$ & $\odot$ & $\oplus$ & $\odot$ & ○ & $\theta$ & ๑ & ๑ & 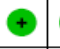 & ๑ & 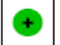 & ๑ & $\odot$ & $\hookrightarrow$ & 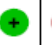 & 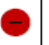 & $?$ \\
\hline Rajab 2019 & $\odot$ & ๑ & $\odot$ & $\theta$ & $\odot$ & $\odot$ & $\odot$ & 3 & $\odot$ & 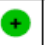 & 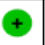 & 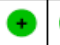 & + & + & $\odot$ & $\odot$ & $\oplus$ & + & $\oplus$ & $\odot$ \\
\hline Ramos-Jorge 2007 & $\odot$ & (†) & $\odot$ & అ & $\odot$ & $\odot$ & $\odot$ & ○ & అ & † & ๑ & ๑ & ๑ & $\odot$ & $\odot$ & ๑ & 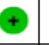 & † & † & $\theta$ \\
\hline Ramos-Jorge 2014 & $\odot$ & $\oplus$ & $\odot$ & $\theta$ & $?$ & $\oplus$ & $\odot$ & $\oplus$ & 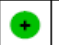 & 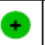 & $\oplus$ & ๑ & $\oplus$ & $\odot$ & అ & $\odot$ & + & $\oplus$ & + & $\oplus$ \\
\hline Sardenberg 2017 & $\odot$ & (†) & $\odot$ & $\odot$ & ๑ & + & † & అ & అ & ๑ & ๑) & ๑ & $\odot$ & 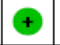 & ๑ & † & $\oplus$ & 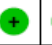 & $\oplus$ & 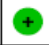 \\
\hline Silva-Oliveira 2018 & $\odot$ & (†) & $\odot$ & ( & $\odot$ & $\odot$ & - & ○ & ○ & ๑ & ๑) & ๑ & $\odot$ & $\odot$ & ๑) & ๑ & 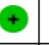 & † & $\boldsymbol{\theta}$ & $?$ \\
\hline Teixeira 2013 & $\odot$ & ๑ & $\odot$ & $\theta$ & $?$ & $\odot$ & $\odot$ & $?$ & $\odot$ & ๑ & ๑ & $\odot$ & $\oplus$ & $\odot$ & $\oplus$ & $\odot$ & $\oplus$ & $\oplus$ & $\theta$ & 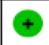 \\
\hline Thelen 2011 & 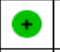 & † & $\odot$ & - & ๑ & $\odot$ & $(+$ & ๑ & $\odot$ & ๑ & + & $\odot$ & $\odot$ & 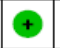 & $\oplus$ & $\odot$ & $\rightarrow$ & - & $\boldsymbol{\theta}$ & 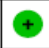 \\
\hline Traebert 2012 & $\oplus$ & $\odot$ & $\odot$ & $\odot$ & $\odot$ & $\odot$ & (๑) & $\ominus$ & $\odot$ & $\oplus$ & $\oplus$ & $\odot$ & $\odot$ & 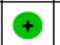 & $\odot$ & $\odot$ & $\oplus$ & $\odot$ & $\boldsymbol{\theta}$ & $\odot$ \\
\hline
\end{tabular}

Figure 4. Quality assessment of included studies summary: review authors' judgements about each risk of bias item for each included study. 
Table 4. Data extraction of included studies-the value of each domain and its impact on OHRQoL.

\begin{tabular}{|c|c|c|c|c|c|c|}
\hline Author/Year & \multicolumn{5}{|c|}{ Value of Each Domain } & \multirow{7}{*}{$\begin{array}{l}\text { Results } \\
\text { Significant association }(p<0.05) \text { between oral symptoms and mother's education and family } \\
\text { income; emotional wellbeing domain and dental caries experience; social wellbeing domain and } \\
\text { children's education, number of siblings; total PCPQ and members in family and dental caries. } \\
\text { Children from public schools and children who had dental caries experience }(\mathrm{RR}=1.28 ; p=0.04 \\
\text { and RR }=1.37 ; p=0.018 \text {, respectively) had a negative impact on total PCPQ scores. Public } \\
\text { school-going children were more likely to experience negative impact on the emotional wellbeing } \\
\text { and social wellbeing domains }(p<0.05) \text {. } \\
\text { Children whose mothers had an educational level }<10 \text { years and children who had dental caries } \\
\text { experience showed positive and negative impact on the oral symptoms domain, respectively } \\
\text { (RR }=0.75, p=0.02 \text { and } \mathrm{RR}=1.22, p=0.04 \text {, respectively). }\end{array}$} \\
\hline \multirow{6}{*}{$\begin{array}{l}\text { Diaz et al. } \\
\text { (2018) [21] }\end{array}$} & P-CPQ & Mean & \multicolumn{2}{|c|}{ SD } & Range & \\
\hline & os & 3.88 & \multicolumn{2}{|c|}{3.5} & $0-20$ & \\
\hline & FL & 3.43 & \multicolumn{2}{|c|}{4.17} & $0-24$ & \\
\hline & EWB & 2.09 & \multicolumn{2}{|c|}{3.90} & $0-30$ & \\
\hline & SWB & 3.09 & \multicolumn{2}{|c|}{6.15} & $0-48$ & \\
\hline & Total score & 12.49 & \multicolumn{2}{|c|}{14.04} & $0-90$ & \\
\hline \multirow{6}{*}{$\begin{array}{c}\text { Antunes et al. } \\
\text { (2012) [37] }\end{array}$} & B-P-CPQ & \multicolumn{2}{|c|}{ A1 } & \multicolumn{2}{|c|}{ A2 } & \multirow{6}{*}{$\begin{array}{l}\text { The group of trauma affecting both dental and support tissue had the highest levels of impact (A1) } \\
\text { and the greatest reduction in impact following therapy (A2). } \\
\text { Positive reduction after receiving the treatment over time was observed for all types of TDI, } \\
\text { indicating that } 100 \% \text { of the population benefitted from trauma treatment. } \\
\text { Post-treatment oral symptoms did positively affect the OHRQoL. However, out of all the domain } \\
\text { scores, oral symptoms had the lowest impact on OHRQoL. } \\
\text { The FL domain had the highest impact on OHRQL. The functional limitations drastically } \\
\text { improved the OHRQL. } \\
\text { The EWB and SWB positively improved the OHRQoL after treatment. Overall post-treatment of } \\
\text { TDI significantly improved the OHRQoL. Out of all four domains tested, EWB and FL improved } \\
\text { and resulted in the highest impact on OHRQoL. }\end{array}$} \\
\hline & $\begin{array}{c}p \text {-value }< \\
0.01\end{array}$ & Mean (SD) & Median & Mean (SD) & Median & \\
\hline & OS(0-24) & $3.36(3.11)$ & 3.00 & $0.05(0.31)$ & 0.00 & \\
\hline & FL(0-32) & $9.83(6.50)$ & 9.50 & $1.38(2.78)$ & 0.00 & \\
\hline & $\operatorname{EWB}(0-28)$ & $9.12(6.60)$ & 10.00 & $0.17(0.70)$ & 0.00 & \\
\hline & SWB(0-40) & $7.74(6.41)$ & 7.00 & $1.07(1.63)$ & 0.00 & \\
\hline \multirow{13}{*}{$\begin{array}{l}\text { Magno et al. } \\
\text { (2019) [38] }\end{array}$} & $\mathrm{CPQ}(8-10)$ & BT & \multicolumn{2}{|c|}{ AT } & $p$-value & \multirow{13}{*}{$\begin{array}{l}\text { OS domain: } \\
\text { CPQ(8-10): There was significant improvement in oral symptoms after treatment. } \\
\text { CPQ(11-14): This observation was not statistically significant. This implied that for children } \\
\text { between } 11-14 \text { years, oral symptoms perception did not affect the OHRQoL. } \\
\text { Overall assessment: This indicated that overall parents perception on OHRQoL in the oral } \\
\text { symptom domain improved after the child received the treatment. } \\
\text { FL domain: The FL domain score for all three questionnaires did not show significant difference in } \\
\text { domain score }(p>0.05) \text {. This result signifies that functional limitations before and post treatment, } \\
\text { both in children and parent perception, did not statistically or significantly impact the OHRQoL. } \\
\text { EWB domain: For CPQ }(8-10) \text {, there was no impact on emotional well-being. CPQ }(11-14) \text { scores } \\
\text { implied that EWB improved post treatment and had positive impact on OHRQoL in children } \\
\text { between the age group of } 11-14 \text { years. } p \text {-CPQ scores indicated no significant difference. } \\
\text { SWB domain: The CPQ }(8-10) \text {, CPQ(11-14), and P-CPQ scores indicated that there was no } \\
\text { statistical significant difference in score in all three groups. This indicated that SWB did not } \\
\text { statistically impact the OHRQoL. } \\
\text { The cumulative scores of all domains indicated that there was significant improvement in } \\
\text { OHRQoL for CPQ(8-10), CPQ(9-14), and P-CPQ after receiving the treatment of TDI. } \\
\text { Familiar Impact Scale (FIS) scores: TDI among children involving enamel and dentine fracture did } \\
\text { not impact family perspective. }\end{array}$} \\
\hline & OS & $5.3(3.4)$ & \multicolumn{2}{|c|}{$2.7(2.9)$} & $0.0003 \mathrm{~b}$ & \\
\hline & FL & $2.6(3.5)$ & \multicolumn{2}{|c|}{$1.7(2.0)$} & $0.4498 \mathrm{~b}$ & \\
\hline & EWB & $1.1(2.8)$ & \multicolumn{2}{|c|}{$0.3(0.7)$} & $0.4990 \mathrm{~b}$ & \\
\hline & SWB & $2.8(3.5)$ & \multicolumn{2}{|c|}{$1.5(1.1)$} & $0.0843 \mathrm{~b}$ & \\
\hline & TOTAL & $10.8(10.0)$ & \multicolumn{2}{|c|}{$6.5(4.5)$} & $0.0065 \mathrm{~b}$ & \\
\hline & CPQ(11-14) & & & & & \\
\hline & OS & $3.2(2.6)$ & \multicolumn{2}{|c|}{$2.4(1.8)$} & $0.37 \mathrm{a}$ & \\
\hline & FL & $2.0(1.6)$ & \multicolumn{2}{|c|}{$1.2(1.6)$} & $0.2049 \mathrm{~b}$ & \\
\hline & EWB & $1.1(1.6)$ & \multicolumn{2}{|c|}{$0.0(0.0)$} & $0.0431 \mathrm{~b}$ & \\
\hline & SWB & $2.5(3.5)$ & \multicolumn{2}{|c|}{$1.3(1.7)$} & $0.1083 \mathrm{~b}$ & \\
\hline & TOTAL & $8.8(5.4)$ & \multicolumn{2}{|c|}{$5.4(2.7)$} & $0.0486 \mathrm{a}$ & \\
\hline & P-CPQ & & & & & \\
\hline
\end{tabular}


Table 4. Cont.

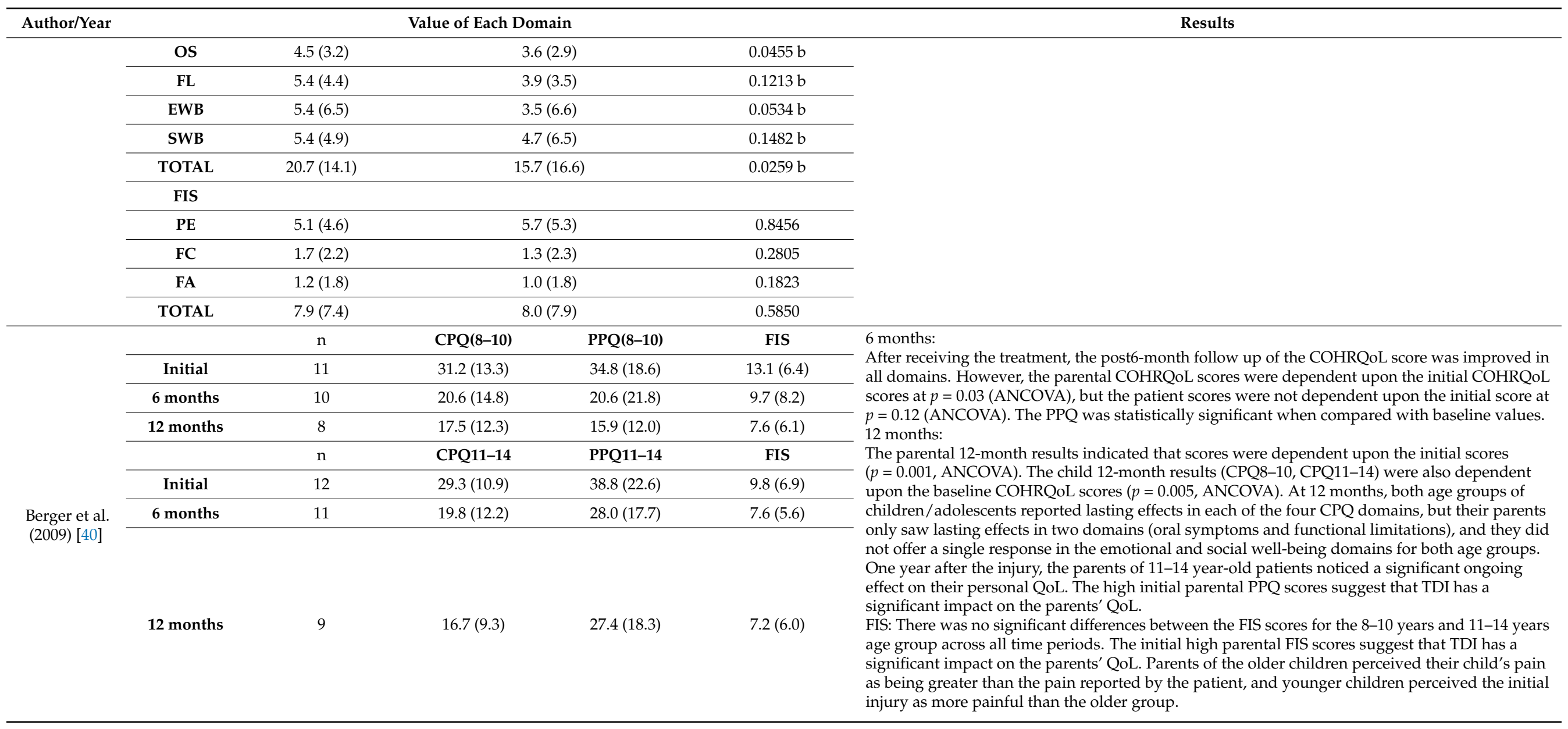


Table 4. Cont.

\begin{tabular}{|c|c|c|c|c|c|c|c|}
\hline Author/Year & & & Value of $E$ & Each Domai & & & Results \\
\hline \multirow{4}{*}{$\begin{array}{l}\text { Martins et al. } \\
\text { (2018) [22] }\end{array}$} & $\begin{array}{c}\text { Variables } \\
\text { Mean (SD) } \\
p \text {-value < } \\
0.001\end{array}$ & OS & FL & EWB & SWB & TOTAL & \multirow{4}{*}{$\begin{array}{l}\text { OS domain: } \\
\text { TDI showed no statistical significant difference with the group that had no oral condition. } \\
\text { However, dental caries associated with TDI had a high negative impact on OHRQoL. } \\
\text { FL domain: } \\
\text { The dental caries children scores were statistically significant with children with TDI at } p=0.001 \\
\text { EWB domain: } \\
\text { In this domain, TDI had no significant impact on OHRQoL. } \\
\text { SWB: } \\
\text { In this domain, TDI had no significant impact on OHRQoL. } \\
\text { Children who presented with dental caries associated with TDI were more likely to experience a } \\
\text { high negative impact on their OHRQoL, as shown by the total score, than those without any oral } \\
\text { condition. The presence of dental caries and its association with TDI were significantly associated } \\
\text { with all CPQ }(8-10) \text { subscales at } p<0.05 \text {. }\end{array}$} \\
\hline & $\begin{array}{c}\text { No } \\
\text { conditions }\end{array}$ & $3.84(3.07)$ & $\begin{array}{c}1.87 \\
(2.72)\end{array}$ & $\begin{array}{c}3.15 \\
(4.08)\end{array}$ & $2.89(4.63)$ & $11.61(11.88)$ & \\
\hline & $\begin{array}{l}\text { Dental } \\
\text { caries }\end{array}$ & $5.31(3.52)$ & $\begin{array}{c}3.02 \\
(3.59)\end{array}$ & $\begin{array}{c}4.82 \\
(4.55)\end{array}$ & $4.36(5.42)$ & $17.50(14.31)$ & \\
\hline & TDI & 3.91(3.16) & $1.53(2.13)$ & $\begin{array}{c}3.39 \\
(4.14)\end{array}$ & $3.06(4.20)$ & $12.03(11.52)$ & \\
\hline \multirow{3}{*}{$\begin{array}{c}\text { Freire-Maia } \\
\text { et al. } \\
\text { (2015) [23] }\end{array}$} & Domain & OR & \multicolumn{2}{|c|}{$95 \%$} & \multicolumn{2}{|c|}{$p$} & \multirow{3}{*}{$\begin{array}{l}\text { Effect of Gender on OHRQL: Girls had a 1.46-fold greater chance of presenting with a negative } \\
\text { impact on OHRQoL. } \\
\text { Effect of trauma status on OHRQoL: Children with severe dental trauma reported a more } \\
\text { negative impact on OHRQoL than children with dental caries and malocclusion involving } \\
\text { increased anterior overjet. } \\
\text { Effect of individual domain score of TDI on OHRQOL: Severe trauma was significantly associated } \\
\text { with a negative impact on overall quality of life (55.9\%). } \\
\text { Trauma did not significantly affect the OS and FL domain, but SWB and EWB egatively affected } \\
\text { the OHRQOL in the bivariate analyses. }\end{array}$} \\
\hline & os & 2.67 & $1.31-5$ & 5.46 & & & \\
\hline & SWB & 2.93 & $1.46-5$ & 5.90 & & & \\
\hline \multirow{6}{*}{$\begin{array}{c}\text { Sardenberg } \\
\text { et al. (2017) } \\
{[24]}\end{array}$} & $\begin{array}{l}\text { CPQ8-10 } \\
\text { Subscales }\end{array}$ & Number of items & Mean ( & (S.D.) & Possible range & Observed range & \multirow{6}{*}{$\begin{array}{l}\text { Effect of gender on OHRQoL: OHRQoL was significantly associated }(p<0.05) \text { with sex. The } \\
\text { CPQ }(8-10) \text { score was } 1.38 \text { times ( } 95 \% \text { CI: } 1.17-1.63 ; p<0.001 \text { ) higher among girls than boys. This } \\
\text { signified that there was a more negative impact on OHRQoL among girls when compared to boys } \\
\text { Socioeconomic status and education level of parents: Negative impact on children's OHRQoL was } \\
\text { significantly associated with a lower parent's / guardian's schooling and lower family income. } \\
\text { Effect of TDI and orofacial dysfunction on OHRQL: A significant negative impact on OHRQLL } \\
\text { associated with a history of TDI (RR: } 1.39 ; 95 \% \text { CI: } 1.15-1.69 \text { ) and orofacial dysfunction (RR: } 1.62 \text {, } \\
95 \% \text { CI: } 1.30-2.02) \text { was seen. } \\
\text { Effect of access to dental care: The children who reported difficulty in having access to dental care } \\
\text { and only sought dental care due to pain or factors other than prevention (RR: } 1.41 ; 95 \% \text { CI: } \\
1.18-1.68 \text { ) were more likely to experience a negative impact on OHRQoL. }\end{array}$} \\
\hline & os & 5 & $5.15(3$ & $3.64)$ & $0-20$ & 0-19 & \\
\hline & FL & 5 & $2.84(3$ & $3.52)$ & $0-20$ & $0-18$ & \\
\hline & EWB & 5 & $3.51(4$ & 4.47) & $0-20$ & $0-20$ & \\
\hline & SWB & 10 & $2.45(4$ & 4.50) & $0-40$ & $0-28$ & \\
\hline & Overall & 25 & $13.95(1$ & 13.12) & $0-100$ & $0-76$ & \\
\hline
\end{tabular}


Table 4. Cont.

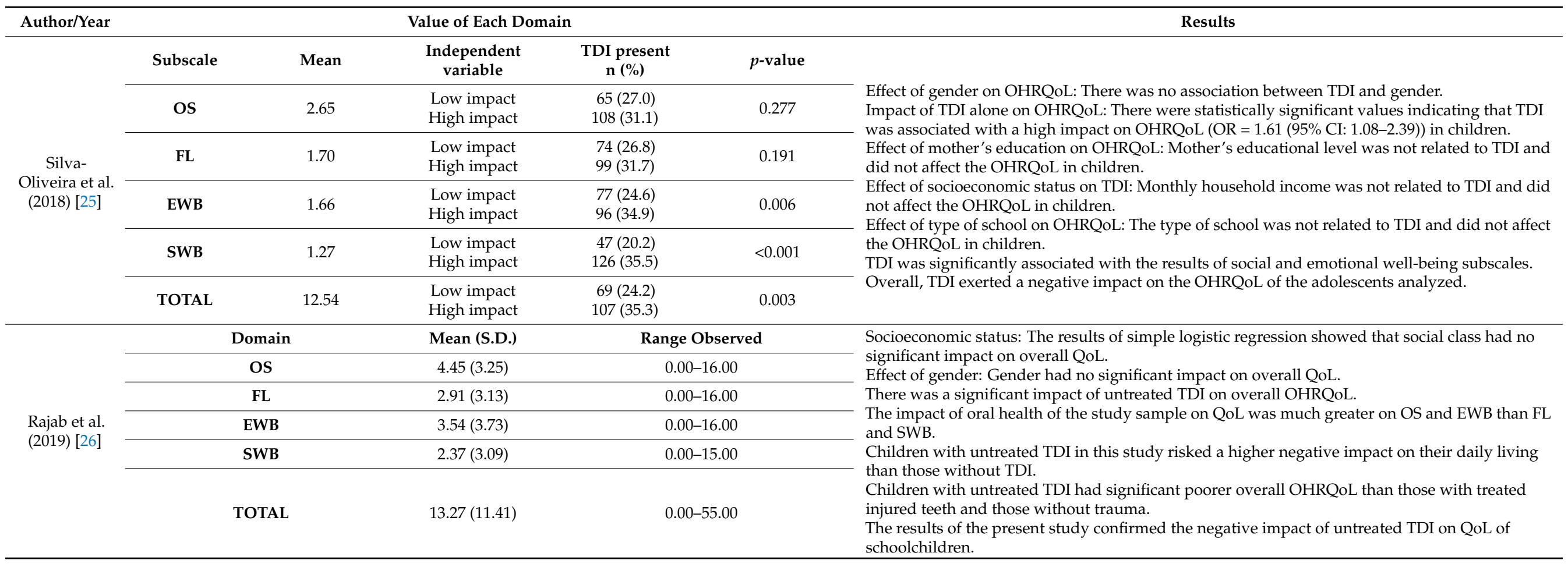


Table 4. Cont.

\begin{tabular}{|c|c|c|c|c|c|c|}
\hline Author/Year & & & Value of Each Dor & & & Results \\
\hline \multirow{12}{*}{$\begin{array}{l}\text { Bendo et al. } \\
\text { (2010) [15] }\end{array}$} & Domain & Untreated TDI & Absence of TDI & $\begin{array}{l}\text { Unadjusted PR } \\
\quad(95 \% \mathrm{CI})\end{array}$ & $\begin{array}{l}p \text {-value t- Chi } \\
\text { square test } \\
\text { †-Fisher's test }\end{array}$ & \multirow{12}{*}{$\begin{array}{l}\text { There were no statistically significant differences between children with untreated TDI and those } \\
\text { without TDI in terms of the overall CPQ(11-14) scores. } \\
\text { There was no association between the overall CPQ11-14-ISF:16 score (Fisher }=0.610) \text { in children } \\
\text { with treated fractures and those without TDI. }\end{array}$} \\
\hline & Os & & & & & \\
\hline & $\begin{array}{c}\text { Pain } \\
\text { CPQ11-14 = } 0 \\
\text { CPQ11-14 } \geq 1\end{array}$ & $\begin{array}{r}81(37.0) \\
138(63.0)\end{array}$ & $\begin{array}{l}541(40.5) \\
796(59.5)\end{array}$ & $\begin{array}{c}1 \\
1.1(0.8-1.5)\end{array}$ & 0.330 & \\
\hline & $\begin{array}{l}\text { Mouth sores } \\
\text { CPQ11-14 = 0 } \\
\text { CPQ11-14 } \geq 1\end{array}$ & $\begin{array}{r}85(38.8) \\
134(61.2)\end{array}$ & $\begin{array}{l}475(35.5) \\
862(64.5)\end{array}$ & $\begin{array}{c}1 \\
0.8(0.6-1.1)\end{array}$ & $0.348+$ & \\
\hline & \multicolumn{5}{|l|}{ FL } & \\
\hline & $\begin{array}{l}\text { Difficulty } \\
\text { chewing } \\
\text { CPQ11-14=0 } \\
\text { CPQ11-14 } \geq 1\end{array}$ & $\begin{array}{l}128(58.4) \\
91(41.6)\end{array}$ & $\begin{array}{l}772(57.7) \\
565(42.3)\end{array}$ & $\begin{array}{c}1 \\
0.9(0.7-1.3)\end{array}$ & $0.844+$ & \\
\hline & $\begin{array}{c}\begin{array}{c}\text { Difficulty } \\
\text { eat- }\end{array} \\
\text { ing/drinking } \\
\text { hot/cold } \\
\text { foods } \\
\text { CPQ11-14 = } 0 \\
\text { CPQ11-14 } \geq 1\end{array}$ & $\begin{array}{r}84(38.4) \\
135(61.6)\end{array}$ & $\begin{array}{l}455(34.0) \\
882(66.0)\end{array}$ & $\begin{array}{c}1 \\
0.8(0.6-1.1)\end{array}$ & $0.212+$ & \\
\hline & \multicolumn{5}{|l|}{ EWB } & \\
\hline & $\begin{array}{l}\text { Felt irrita- } \\
\text { ble/frustrated } \\
\text { CPQ11-14 =0 } \\
\text { CPQ11-14 } \geq 1\end{array}$ & $\begin{array}{l}138(63.0) \\
81(37.0)\end{array}$ & $\begin{array}{l}827(61.9) \\
510(38.1)\end{array}$ & $\begin{array}{c}1 \\
0.9(0.7-1.2)\end{array}$ & $0.743+$ & \\
\hline & $\begin{array}{c}\text { Upset } \\
\text { CPQ11-14 = } 0 \\
\text { CPQ11-14 } \geq 1\end{array}$ & $\begin{array}{l}118(53.9) \\
101(46.1)\end{array}$ & $\begin{array}{l}795(59.5) \\
542(40.5)\end{array}$ & $\begin{array}{c}1 \\
1.2(0.9-1.6)\end{array}$ & $0.120+$ & \\
\hline & 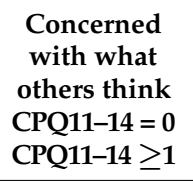 & $\begin{array}{l}107(48.9) \\
112(51.1)\end{array}$ & $\begin{array}{l}548(41.0) \\
789(59.0)\end{array}$ & $\begin{array}{c}1 \\
0.7(0.5-0.9)\end{array}$ & $0.029+$ & \\
\hline & SWB & & & & & \\
\hline
\end{tabular}


Table 4. Cont.

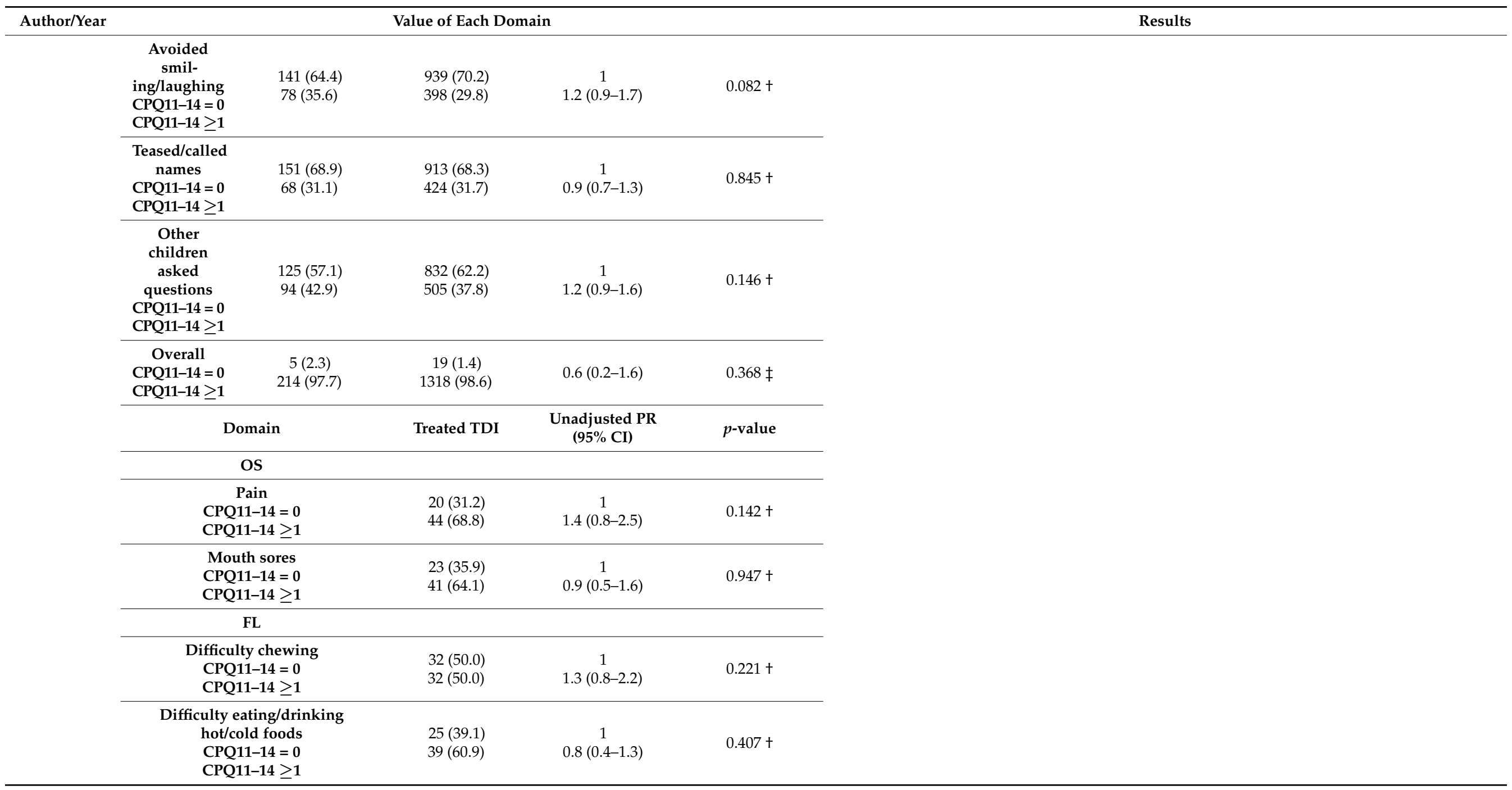


Table 4. Cont.

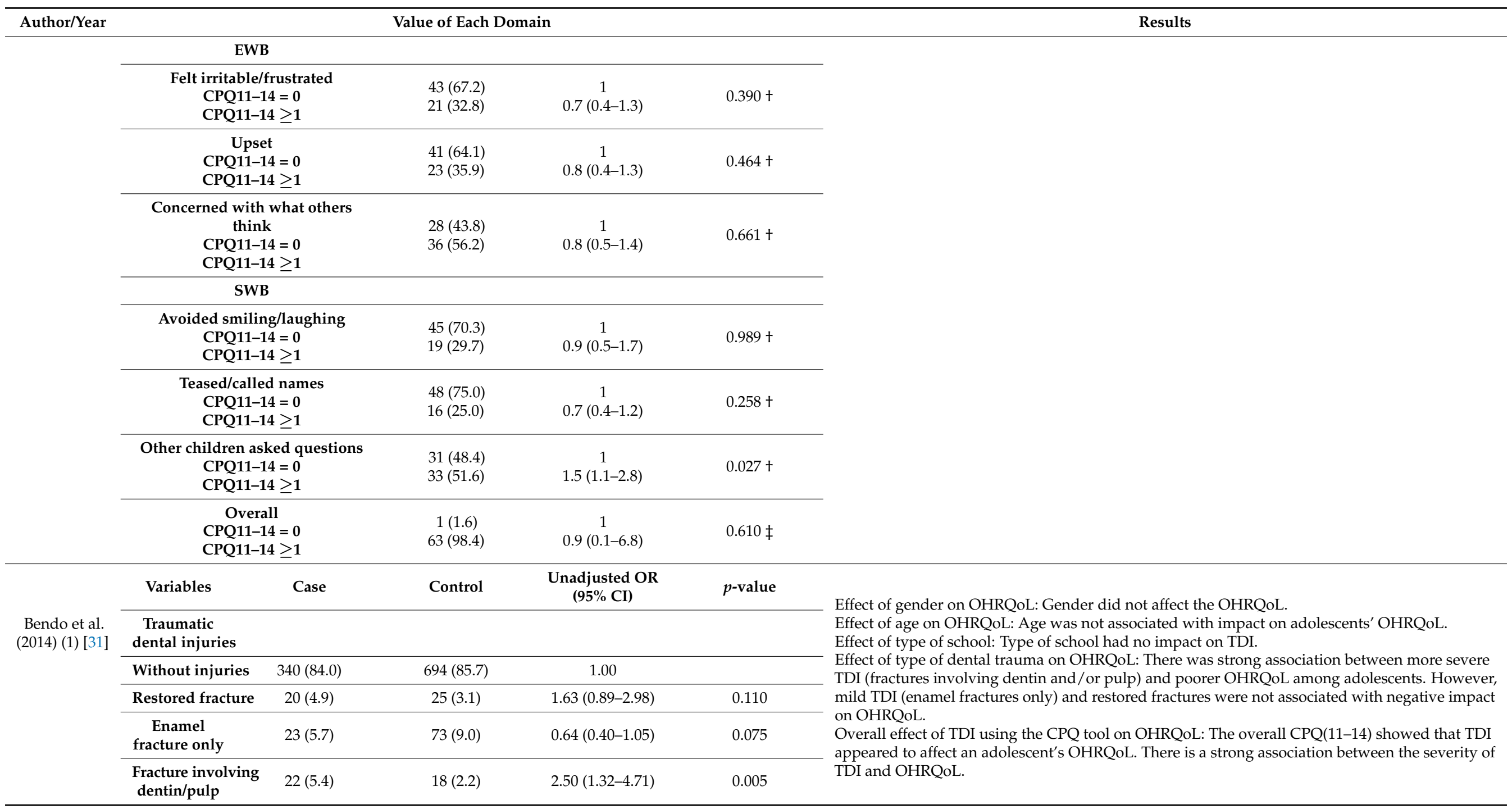


Table 4. Cont.

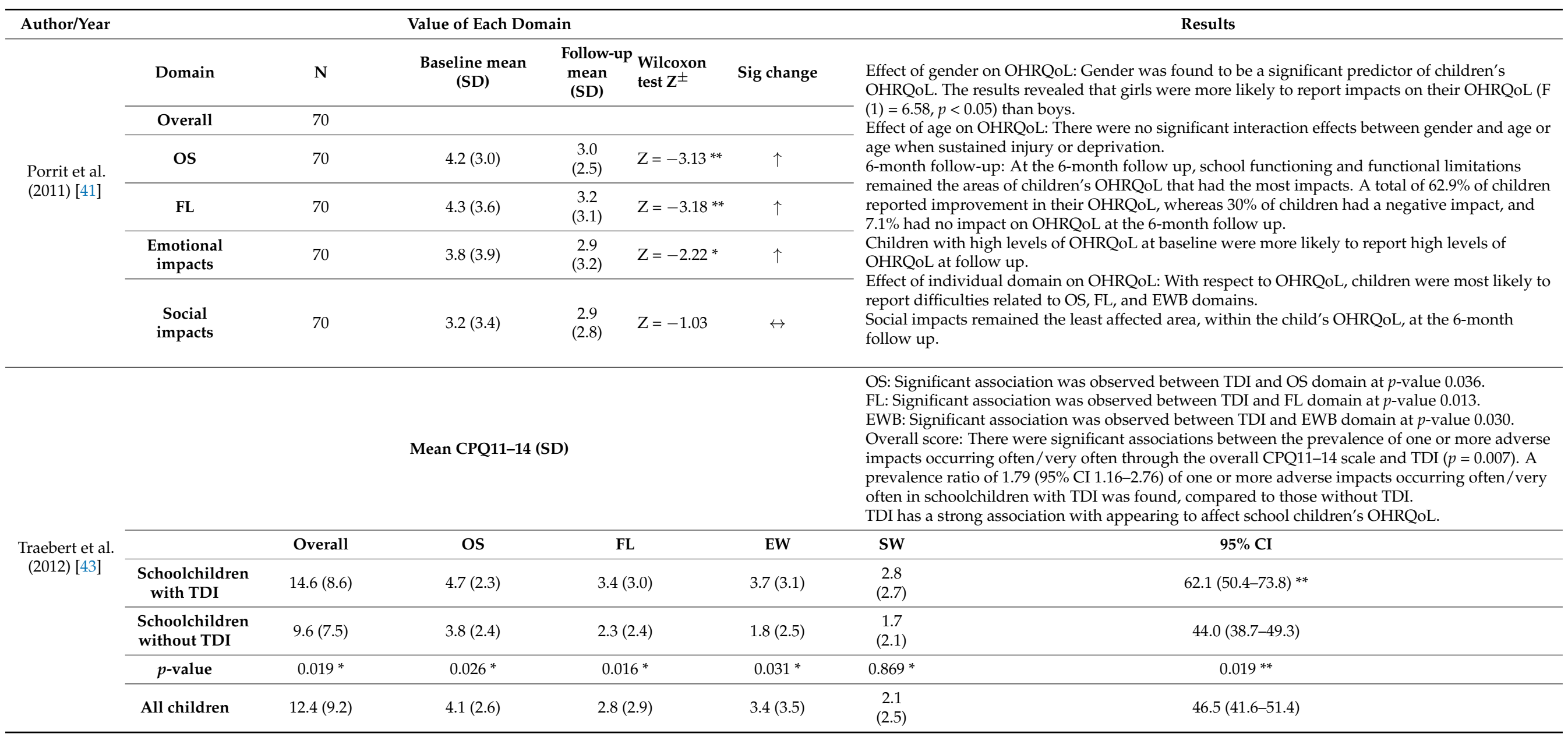


Table 4. Cont.

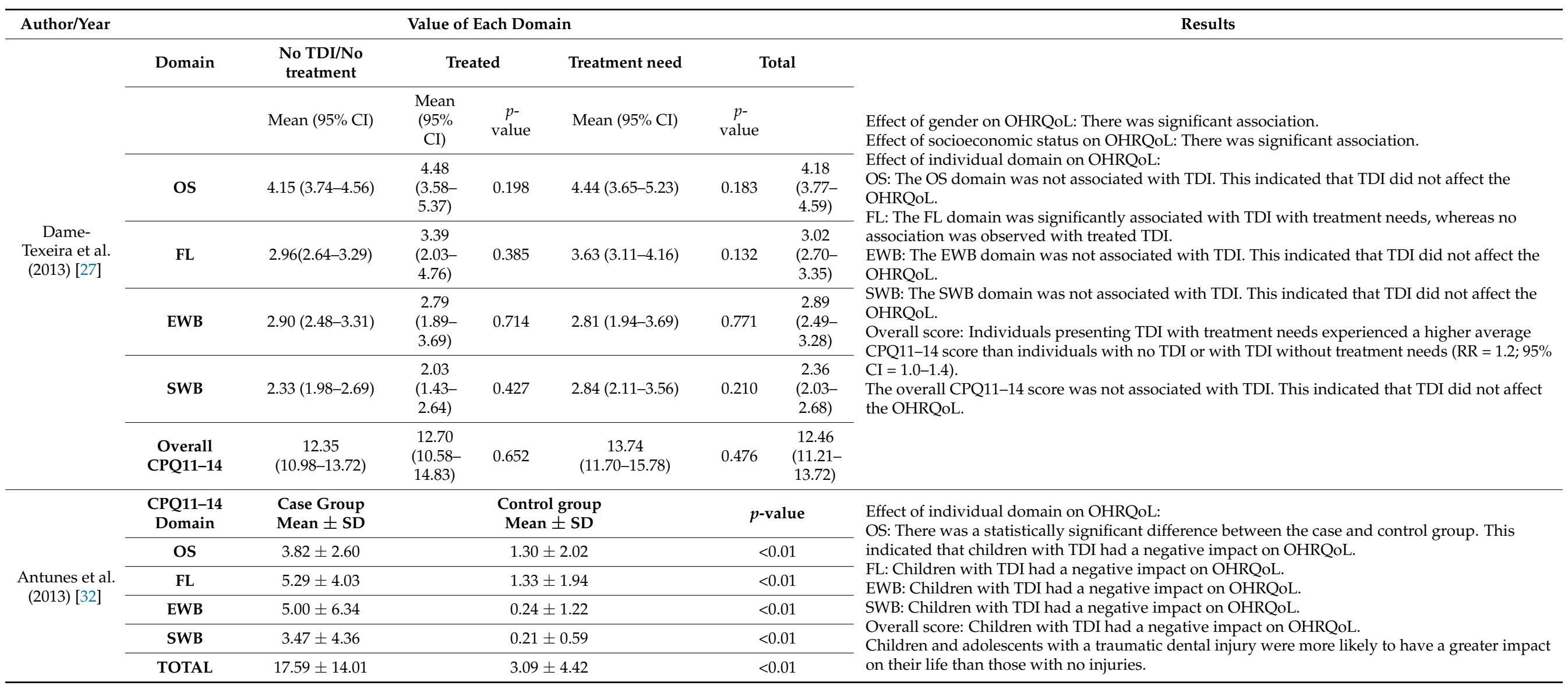


Table 4. Cont.

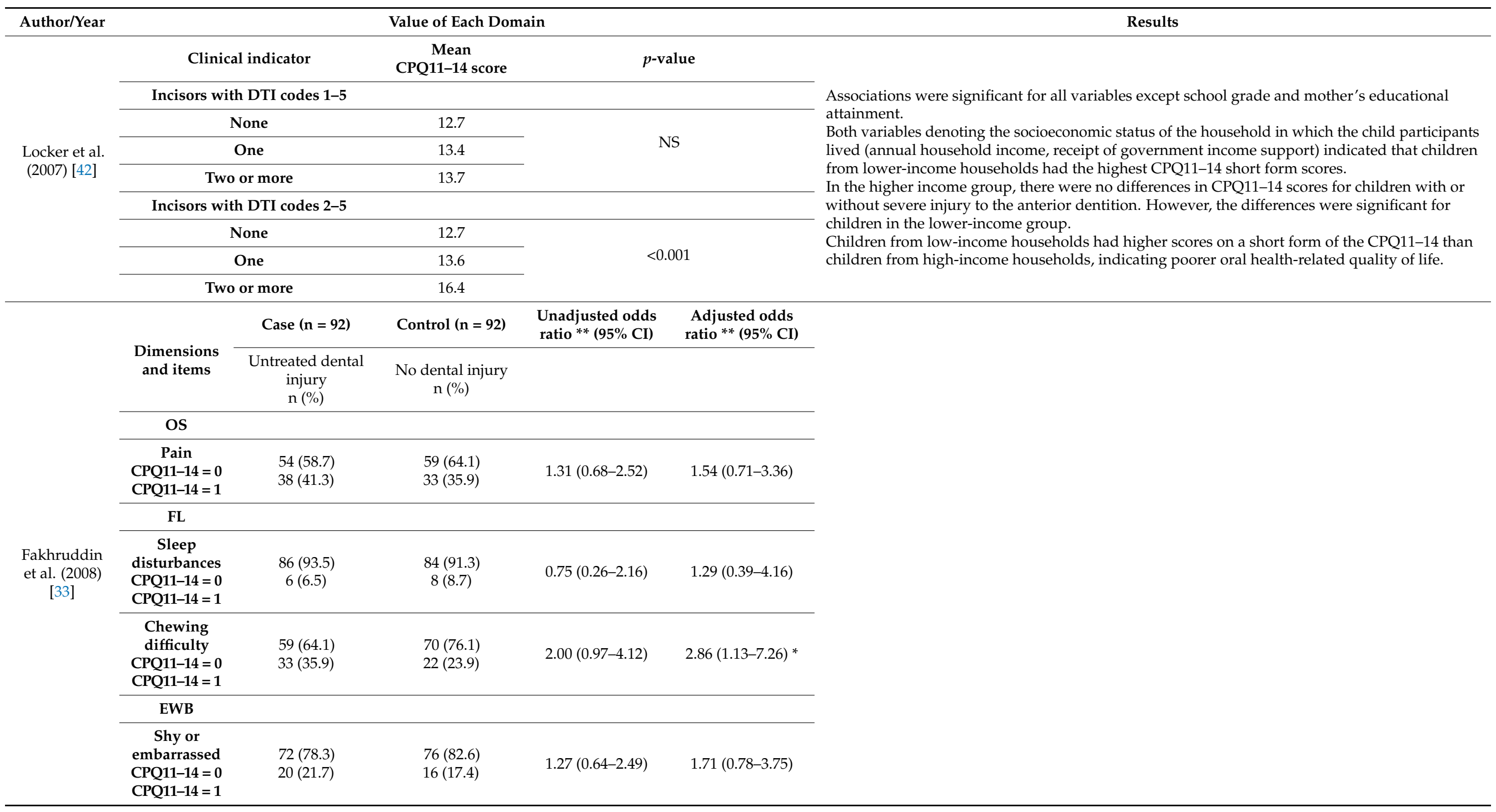


Table 4. Cont.

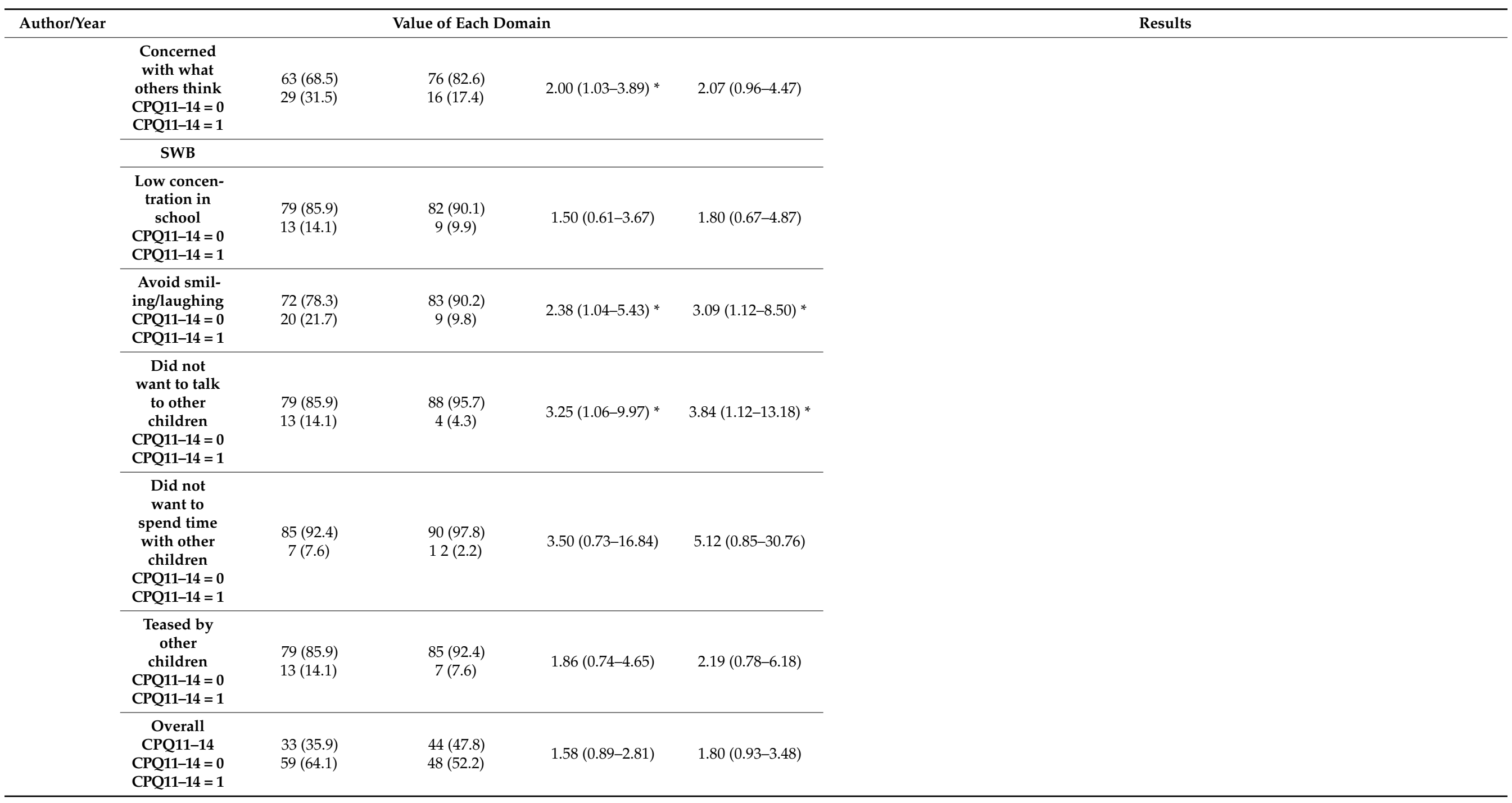


Table 4. Cont.

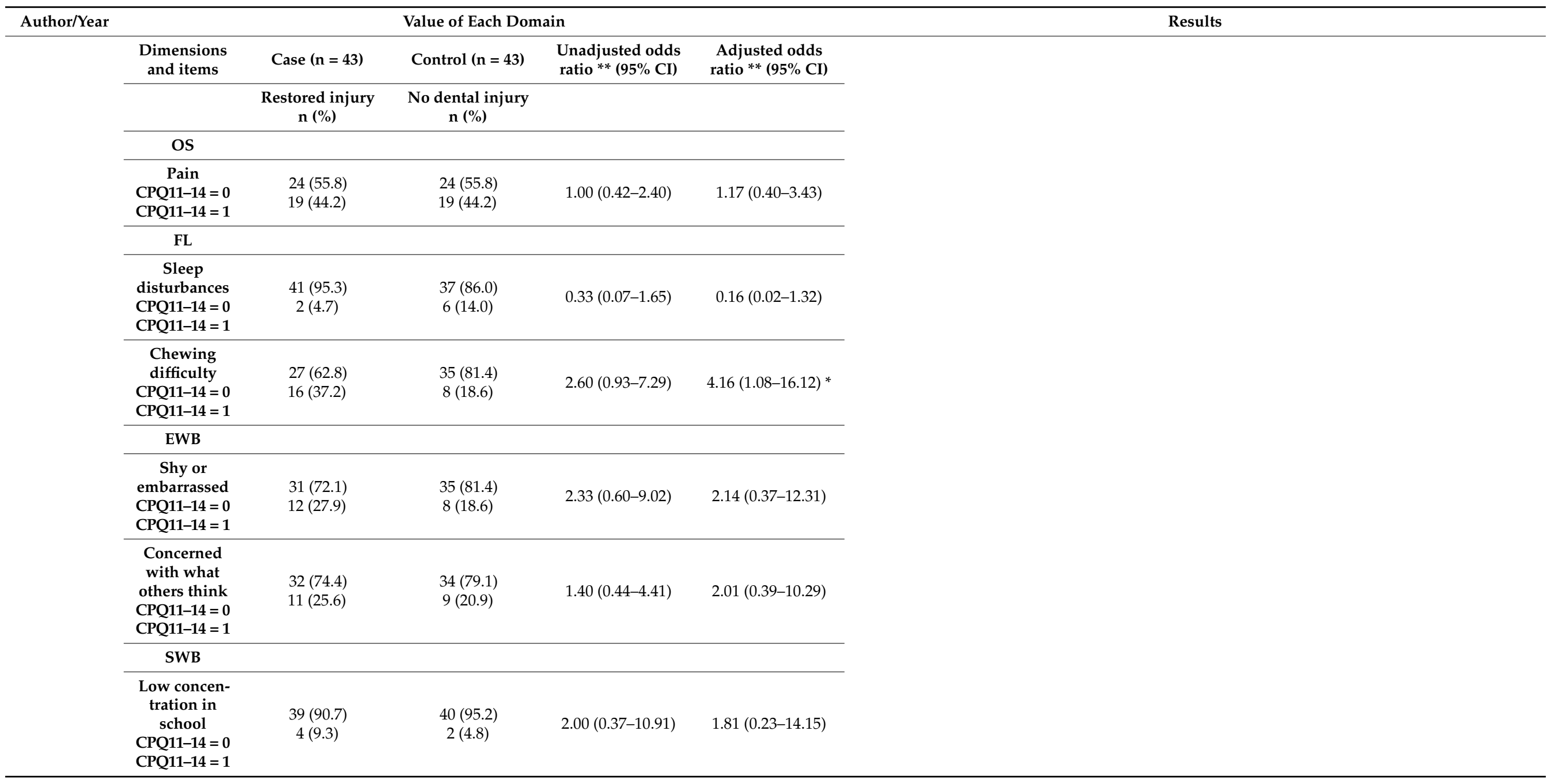


Table 4. Cont.

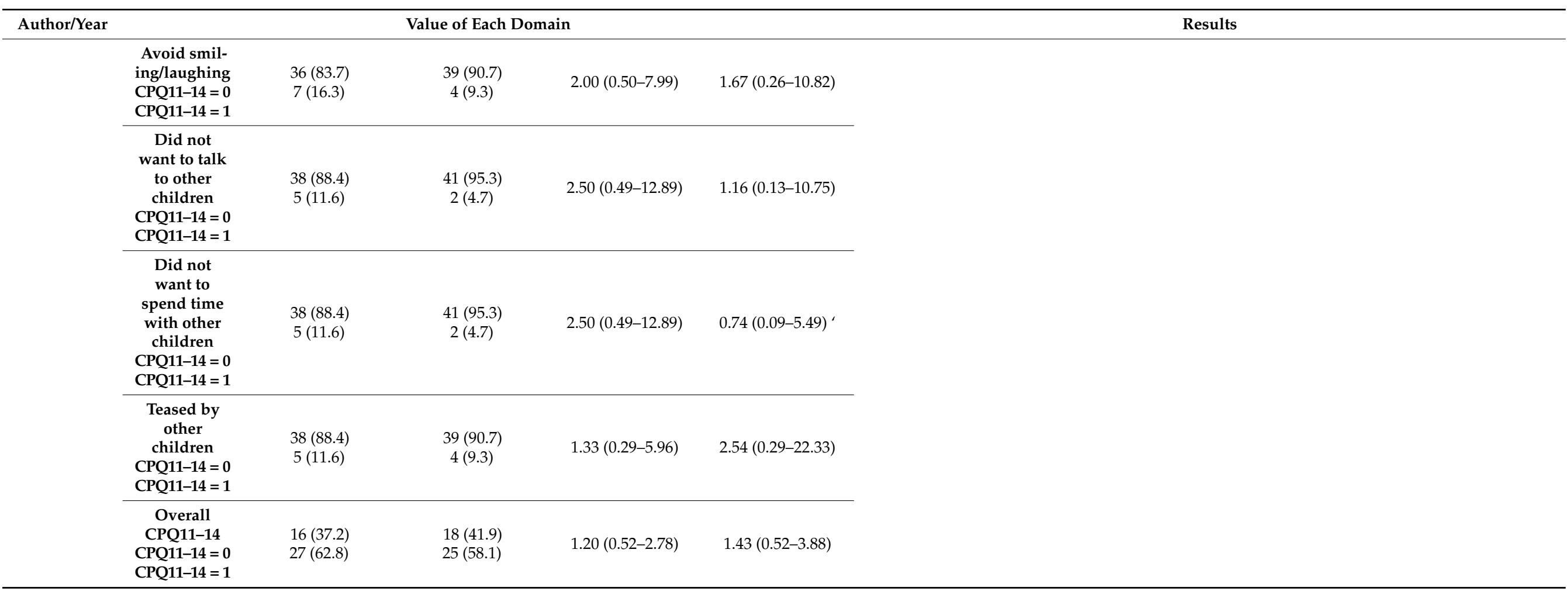


Table 4. Cont.

\begin{tabular}{|c|c|c|c|c|c|c|c|}
\hline Author/Year & \multicolumn{6}{|c|}{ Value of Each Domain } & Results \\
\hline \multirow{4}{*}{$\begin{array}{l}\text { Bendo et al. } \\
\text { (2014) (2) [29] }\end{array}$} & Variables & $\begin{array}{c}\text { Overall } \\
\text { B-FIS } \\
\text { Ro- } \\
\text { bust } \\
\text { RR } \\
(95 \% \\
\text { CI) }\end{array}$ & $\begin{array}{l}\text { Parental/ } \\
\text { family } \\
\text { activ- } \\
\text { ity } \\
\text { Robust } \\
\text { RR } \\
(95 \% \\
\text { CI) }\end{array}$ & $\begin{array}{c}\text { Parental } \\
\text { emotions } \\
\text { Robust RR (95\% } \\
\text { CI) }\end{array}$ & $\begin{array}{l}\text { Family conflict } \\
\text { Robust RR }(95 \% \\
\text { CI) }\end{array}$ & $\begin{array}{l}\text { Financial burden } \\
\text { Robust RR }(95 \% \\
\text { CI) }\end{array}$ & \multirow{4}{*}{$\begin{array}{l}\text { Effect of individual domain: } \\
\text { Parental/ family activity: Parents/caregivers of adolescents who had suffered a fracture involving } \\
\text { the dentine or dentine/pulp had higher scores on the parental/family activity subscale than those } \\
\text { whose adolescents were diagnosed with an absence of TDI or enamel fracture alone. Greater } \\
\text { social vulnerability had a negative impact on families' QoL regarding parental/family activity. } \\
\text { The severity of the TDI was significantly associated with negative impacts on the parental activity } \\
\text { Parental emotions: Greater social vulnerability had a negative impact on families' QoL regarding } \\
\text { parental emotions. The severity of the TDI was significantly associated with negative impacts on } \\
\text { the parental emotion subscale. } \\
\text { Family conflict: Greater social vulnerability had a negative impact on families' QoL regarding the } \\
\text { family conflict subscales. The severity of the TDI was significantly associated with negative } \\
\text { impacts on the family conflict subscales. } \\
\text { Financial burden: There was absence of impact on the financial burden subscale, which reflects } \\
\text { the fact that TDI is not considered a disease by most parents. } \\
\text { Overall score: Parents/caregivers of adolescents who had suffered a fracture involving the } \\
\text { dentine or dentine/pulp had higher scores on overall B-FIS than those whose adolescents were } \\
\text { diagnosed with an absence of TDI or enamel fracture alone. Greater social vulnerability had a } \\
\text { negative impact on families' QoL regarding the overall B-FIS. Adolescents with a fracture of } \\
\text { dentine or dentine/pulp had a } 44 \% \text {-higher chance of increasing their overall B-FIS score by one } \\
\text { point (RR = } 1.44 ; 95 \% \text { zx CI; } 1.10-1.88 \text { ) than those without TDI. A fracture involving dentin or } \\
\text { dentin/pulp was associated with a greater likelihood of a negative impact on family's QoL. }\end{array}$} \\
\hline & $\begin{array}{c}\text { TDI } \\
\text { absent }\end{array}$ & 1.00 & 1.00 & 1.00 & 1.00 & 1.00 & \\
\hline & $\begin{array}{l}\text { Enamel } \\
\text { fracture } \\
\text { alone }\end{array}$ & $\begin{array}{l}0.96 \\
(0.77- \\
1.18)\end{array}$ & $\begin{array}{l}1.04 \\
(0.82- \\
1.32)\end{array}$ & $0.87(0.67-1.12)$ & $0.98(0.73-1.30)$ & $0.78(0.52-1.16)$ & \\
\hline & $\begin{array}{c}\text { Fracture } \\
\text { involving } \\
\text { dentine or } \\
\text { den- } \\
\text { tine/pulp }\end{array}$ & $\begin{array}{c}1.44 \\
(1.10- \\
1.88) \\
* *\end{array}$ & $\begin{array}{c}1.45 \\
(1.09- \\
1.94) \\
*\end{array}$ & $1.45(1.03-2.04)$ * & $1.46(1.01-2.11) *$ & $1.26(0.79-2.00)$ & \\
\hline \multirow{4}{*}{$\begin{array}{l}\text { Gianenetti } \\
\text { et al. (2007) } \\
{[39]}\end{array}$} & \multicolumn{3}{|c|}{$\begin{array}{c}\text { Age } \\
\% \text { under } 18 \text { years old }\end{array}$} & \multicolumn{3}{|c|}{$72.27(73)$} & \multirow{4}{*}{$\begin{array}{l}\text { Adverse impacts on OHRQoL were reported much more frequently among patients who got into } \\
\text { failure of replantation compared with patients who got into successful replantation. If patients got } \\
\text { into tooth avulsion, then their quality of life was adversely affected. }\end{array}$} \\
\hline & & $\begin{array}{l}\text { Sex } \\
\text { Male } \\
\text { Female }\end{array}$ & & & $\begin{array}{l}63.4(64) \\
36.6(37)\end{array}$ & & \\
\hline & $\begin{array}{r}\text { Too } \\
\% \text { cet } \\
\% \text { lat } \\
\% \text { more } t\end{array}$ & $\begin{array}{l}\text { Avulsed } \\
\text { al incisors } \\
\text { al incisors } \\
\text { n one elen }\end{array}$ & nent & & $\begin{array}{l}49.5(50) \\
13.8(14) \\
36.7(37)\end{array}$ & & \\
\hline & \multicolumn{3}{|c|}{$\begin{array}{l}\text { Time since last dental visit } \\
\% \text { visited in last month }\end{array}$} & & $39.6(40)$ & & \\
\hline
\end{tabular}


Table 4. Cont.

\begin{tabular}{|c|c|c|c|c|c|c|}
\hline Author/Year & & & Value of Each Do & & & Results \\
\hline \multirow{7}{*}{$\begin{array}{l}\text { Bomfim et al. } \\
\text { (2017) [30] }\end{array}$} & Trauma & $\mathrm{n}$ & $\%$ & & & \\
\hline & Maxillary & 1344 & 18.56 & 17.68 & 19.47 & \multirow{6}{*}{$\begin{array}{l}\text { Effect of family income on OHRQoL: } \\
\text { Income level had no association with TDI. This indicated that family income did not impact the } \\
\text { OHRQoL. } \\
\text { Effect of parent's education on OHRQoL: Parents education was not associated with TDI outcome } \\
\text { This indicated that parental education did not impact the OHRQoL. } \\
\text { Effect of trauma on OHRQoL: Enamel fractures were risk factors for feelings of shame among } \\
\text { children (OR } 1.27 \text { and } 95 \% C I: 1: 05-1: 53 \text { ) and were significantly associated with embarrassment of } \\
\text { smiling, whereas dentine/enamel fractures were risk factors for dissatisfaction with their teeth or } \\
\text { for feeling embarrassed of smiling and messing up with the study. This type of TDI was also } \\
\text { associated with the unadjusted coefficient used to report difficulty with eating. This indicated that } \\
\text { dentin fracture or fractures involving pulp impacted the OHRQL negatively. Mandibular tooth } \\
\text { fractures did not affect the quality of life of } 12-\text {-year-old Brazilian children. The greater the severity } \\
\text { of the TDI, the greater its impact on OHRQoL. TDI causes aesthetic, emotional, and functional } \\
\text { problems in patients that might be irreversible in some cases. }\end{array}$} \\
\hline & Mandibular & 391 & 5.4 & 4.9 & 5.9 & \\
\hline & Enamel & 1378 & 19.03 & 18.1 & 20 & \\
\hline & Dentine & 271 & 3.7 & 3.32 & 4.2 & \\
\hline & $\begin{array}{c}\text { Pulp } \\
\text { exposition }\end{array}$ & 22 & 0.3 & 0.2 & 0.4 & \\
\hline & Avulsion & 12 & 0.17 & 0.1 & 0.3 & \\
\hline \multirow{5}{*}{$\begin{array}{c}\text { Ramos-Jorge } \\
\text { et al. } \\
\text { (2014) [9] }\end{array}$} & Variables & $\begin{array}{c}\text { Without TDI } \\
\text { n (\%) }\end{array}$ & $\begin{array}{c}\text { Untreated TDI } \\
\text { n (\%) }\end{array}$ & $\begin{array}{l}\text { Treated TDI } \\
\text { n (\%) }\end{array}$ & $p$ & \multirow{5}{*}{$\begin{array}{l}\text { Effect of mother's education on OHRQoL: There was a statistically significant difference for } \\
\text { mother's schooling in comparison of schoolchildren without TDI and those with treated TDI. } \\
\text { Effect of individual items on OIDP: Children with untreated TDI experienced a greater negative } \\
\text { impact on QoL in comparison with those without TDI in eating and enjoying food and smiling } \\
\text { and showing teeth. } \\
\text { No impact on OIDP was seen in all children in the treated TDI group for cleaning mouth, } \\
\text { speaking, sleeping, and relaxing. } \\
\text { No impact on OIDP was seen in all children in the no TDI group, untreated TDI, or in treated TDI } \\
\text { group in maintaining usual emotional state and carrying out school-related tasks. } \\
\text { Enjoying contact with people: Impact on OIDP was seen in } 0.2 \% \text { of children in the without TDI } \\
\text { group and no impact on OIDP was seen in all children in the untreated TDI group and treated } \\
\text { TDI group. } \\
\text { Overall: Children with untreated TDI experienced a greater negative impact on QoL in } \\
\text { comparison with those without TDI. }\end{array}$} \\
\hline & $\begin{array}{l}\begin{array}{c}\text { Eating and } \\
\text { enjoying } \\
\text { food }\end{array} \\
\text { Child-OIDP = } 0 \\
\text { Child-OIDP } \geq 1\end{array}$ & $\begin{array}{l}419(95.4) \\
20(4.6)\end{array}$ & $\begin{array}{c}148(90.2) \\
16(9.8)\end{array}$ & $\begin{array}{c}59(90.8) \\
6(9.2)\end{array}$ & $\begin{array}{c}\text { Without vs. } \\
\text { Untreated }=0.016 \\
\text { Without vs. } \\
\text { Treated }=0.128\end{array}$ & \\
\hline & $\begin{array}{c}\begin{array}{c}\text { Cleaning } \\
\text { mouth } \\
\text { Child-OIDP }=0 \\
\text { Child-OIDP } \geq 1\end{array} \\
\end{array}$ & $\begin{array}{l}428(97.5) \\
11(2.5)\end{array}$ & $\begin{array}{c}162(98.8) \\
2(1.2)\end{array}$ & $65(100.0)$ & $\begin{array}{c}\text { Without vs. } \\
\text { Untreated }=0.530 \\
\text { Without vs. } \\
\text { Treated }=0.3742\end{array}$ & \\
\hline & $\begin{array}{c}\text { Speaking } \\
\text { Child-OIDP }=0 \\
\text { Child-OIDP } \geq 1\end{array}$ & $\begin{array}{c}434(98.9) \\
5(1.1)\end{array}$ & $\begin{array}{c}159(97.0) \\
5(3.0)\end{array}$ & $65(100.0)$ & $\begin{array}{c}\text { Without vs. } \\
\text { Untreated }=0.145 \\
\text { Without vs. } \\
\text { Treated }=1.000\end{array}$ & \\
\hline & $\begin{array}{l}\text { Sleeping } \\
\text { and relaxing } \\
\text { Child-OIDP }=0 \\
\text { Child-OIDP } \geq 1\end{array}$ & $\begin{array}{c}435(99.1) \\
4(0.9)\end{array}$ & $\begin{array}{c}163(99.4) \\
1(0.6)\end{array}$ & $\begin{array}{c}65(100.0) \\
-\end{array}$ & $\begin{array}{c}\text { Without vs. } \\
\text { Untreated }=1.000 \\
\text { Without vs. } \\
\text { Treated }=1.000\end{array}$ & \\
\hline
\end{tabular}


Table 4. Cont.

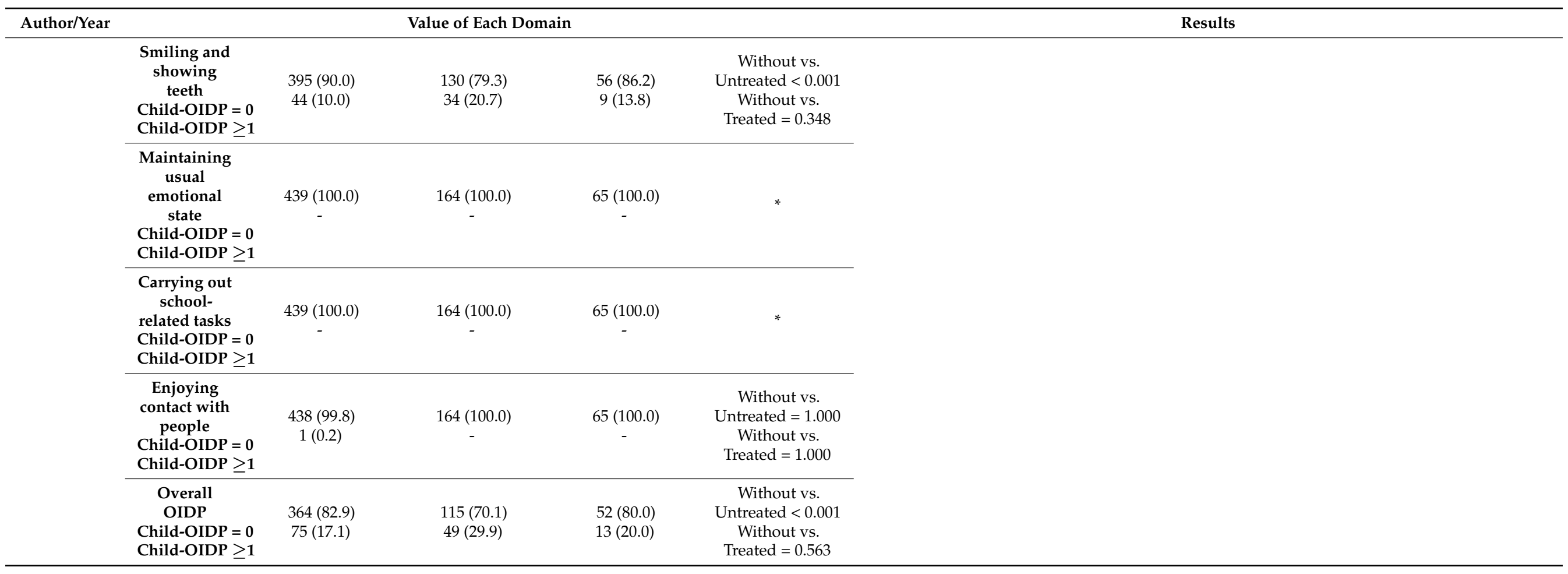


Table 4. Cont.

\begin{tabular}{|c|c|c|c|c|c|c|}
\hline Author/Year & & & Value of Each Do & & & Results \\
\hline \multirow{10}{*}{$\begin{array}{l}\text { Thelen et al. } \\
\text { (2011) [34] }\end{array}$} & Variables & Cases n (\%) & Controls n (\%) & $\begin{array}{l}\text { OR-unadjusted } \\
(\mathrm{CI}=95 \%)\end{array}$ & $\begin{array}{c}\text { OR-adjusted } \\
(\mathrm{CI}=95 \%)\end{array}$ & \multirow{10}{*}{$\begin{array}{l}\text { Effect of individual items on OHRQoL: } \\
\text { Eating and enjoying food: A total of } 46.3 \% \text { of cases and } 34.2 \% \text { of controls had an impact on OIDP } \\
\text { Cleaning mouth: A total of } 28.4 \% \text { of cases and } 28.4 \% \text { of controls had an impact on OIDP. } \\
\text { Speaking: A total of } 3.2 \% \text { of cases and } 8.9 \% \text { of controls had an impact on OIDP. } \\
\text { Sleeping and relaxing: A total of } 18.9 \% \text { of cases and } 18.4 \% \text { of controls had an impact on OIDP. } \\
\text { Smiling and showing teeth: A total of } 78.9 \% \text { of cases and } 31.6 \% \text { of controls had an impact on OIDP } \\
\text { This item showed the most prevalent impact on OHRQoL. Statistical significant difference was } \\
\text { observed between cases and controls. } \\
\text { Maintaining usual emotional state: A total of } 31.6 \% \text { of cases and } 20 \% \text { of controls had an impact on } \\
\text { OIDP. A significant difference was found between cases and controls at } p \text {-value }<0.05 \text {. } \\
\text { Carrying out school-related tasks: A total of } 4.2 \% \text { cases of and } 11.6 \% \text { of controls had an impact on } \\
\text { OIDP. } \\
\text { Enjoying contact with people: A total of } 66.3 \% \text { of cases and } 23.2 \% \text { of controls had an impact on } \\
\text { OIDP. This item had the second-most prevalent impact, which was significantly more in cases } \\
\text { than controls at } p \text {-value }<0.001 \text {. Statistical significant difference was observed between cases and } \\
\text { controls. } \\
\text { Overall score: The overall impact prevalence of OIDP among cases was significantly higher } \\
(88.4 \%) \text { than for the controls ( } 58.9 \%)(p<0.001) \text {. There was a significantly greater probability of } \\
\text { perceiving an oral impact on daily life among cases than controls. TDI with unmet treatment need } \\
\text { in this sample of adolescents was associated with reduced OHRQoL. Compared to adolescents } \\
\text { with no history of TDI, those affected by TDI with unmet treatment need were at greater risk of } \\
\text { suffering impacts on OHRQoL in the form of OIDP. }\end{array}$} \\
\hline & $\begin{array}{l}\text { Eating and } \\
\text { enjoying food } \\
\text { OIDP }=0 \\
\text { OIDP } \geq 1\end{array}$ & $\begin{array}{l}51(53.7) \\
44(46.3)\end{array}$ & $\begin{array}{l}125(65.8) \\
65(34.2)\end{array}$ & $\begin{array}{c}1 \\
1.7(1.01-2.78) \\
p<0.05\end{array}$ & $\begin{array}{c}1 \\
1.01(0.6-2.1)\end{array}$ & \\
\hline & $\begin{array}{l}\text { Cleaning } \\
\text { your mouth } \\
\text { OIDP }=0 \\
\text { OIDP } \geq 1\end{array}$ & $\begin{array}{l}68(71.6) \\
27(28.4)\end{array}$ & $\begin{array}{l}136(71.6) \\
54(28.4)\end{array}$ & $\begin{array}{c}1 \\
0.3(0.08-1.2)\end{array}$ & $\begin{array}{c}1 \\
0.2(0.06-1.1)\end{array}$ & \\
\hline & $\begin{array}{l}\text { Speaking } \\
\text { OIDP }=0 \\
\text { OIDP } \geq 1\end{array}$ & $\begin{array}{c}92(96.8) \\
3(3.2)\end{array}$ & $\begin{array}{c}173(91.1) \\
17(8.9)\end{array}$ & $\begin{array}{c}1 \\
1.2(0.5-1.7)\end{array}$ & $\begin{array}{c}1 \\
0.9(0.5-1.9)\end{array}$ & \\
\hline & $\begin{array}{c}\text { Sleeping } \\
\text { and relaxing } \\
\text { OIDP }=0 \\
\text { OIDP } \geq 1\end{array}$ & $\begin{array}{l}77(81.1) \\
18(18.9)\end{array}$ & $\begin{array}{l}155(81.6) \\
35(18.4)\end{array}$ & $\begin{array}{c}1 \\
1.1(0.6-1.9)\end{array}$ & $\begin{array}{c}1 \\
0.8(0.4-1.6)\end{array}$ & \\
\hline & $\begin{array}{l}\text { Smiling and } \\
\text { showing teeth } \\
\text { OIDP }=0 \\
\text { OIDP } \geq 1\end{array}$ & $\begin{array}{l}20(21.1) \\
75(78.9)\end{array}$ & $\begin{array}{l}130(68.4) \\
60(31.6)\end{array}$ & $\begin{array}{c}1 \\
8.4(4.2-16.5) \\
p<0.001\end{array}$ & $\begin{array}{c}1 \\
10.9(4.5-26.6) \\
p<0.001\end{array}$ & \\
\hline & $\begin{array}{l}\text { Maintaining } \\
\text { usual } \\
\text { emotional state } \\
\text { OIDP }=0 \\
\text { OIDP } \geq 1\end{array}$ & $\begin{array}{l}65(68.4) \\
30(31.6)\end{array}$ & $\begin{array}{l}152(80.0) \\
38(20.0)\end{array}$ & $\begin{array}{c}1 \\
1.8(1.1-3.2) \\
p<0.05\end{array}$ & $\begin{array}{c}1 \\
1.8(0.9-3.6)\end{array}$ & \\
\hline & $\begin{array}{l}\text { Carrying out } \\
\text { school } \\
\text { related tasks } \\
\text { OIDP }=0 \\
\text { OIDP } \geq 1\end{array}$ & $\begin{array}{c}91(95.8) \\
4(4.2)\end{array}$ & $\begin{array}{l}168(88.4) \\
22(11.6)\end{array}$ & $\begin{array}{c}1 \\
0.4(0.1-1.1)\end{array}$ & $\begin{array}{c}1 \\
0.5(0.1-1.8)\end{array}$ & \\
\hline & $\begin{array}{l}\text { Enjoying contact } \\
\text { with people } \\
\text { OIDP }=0 \\
\text { OIDP } \geq 1\end{array}$ & $\begin{array}{l}32(33.7) \\
63(66.3)\end{array}$ & $\begin{array}{l}146(76.8) \\
44(23.2)\end{array}$ & $\begin{array}{c}1 \\
5.6(3.2-9.8) \\
p<0.001\end{array}$ & $\begin{array}{c}1 \\
6.1(3.1-12.1) \\
p<0.001\end{array}$ & \\
\hline & $\begin{array}{c}\text { Overall OIDP } \\
\text { OIDP }=0 \\
\text { OIDP } \geq 1\end{array}$ & $\begin{array}{l}11(11.6) \\
84(88.4)\end{array}$ & $\begin{array}{r}78(41.1) \\
112(58.9)\end{array}$ & $\begin{array}{c}1 \\
5(2.4-10.2) \\
p<0.001\end{array}$ & $\begin{array}{c}1 \\
3.9(1.6-9.1) \\
p<0.05\end{array}$ & \\
\hline
\end{tabular}


Table 4. Cont.

\begin{tabular}{|c|c|c|c|c|c|c|}
\hline Author/Year & & & Value of Each Do & & & Results \\
\hline \multirow{8}{*}{$\begin{array}{l}\text { Cortes et al. } \\
\text { (2002) [35] }\end{array}$} & Variable & Cases n (\%) & Controls n (\%) & $\begin{array}{l}\text { OR-unadjusted } \\
\quad(\mathrm{CI}=95 \%)\end{array}$ & $\begin{array}{l}\text { OR-adjusted } \\
(\mathrm{CI}=95 \%)\end{array}$ & \multirow{8}{*}{$\begin{array}{l}\text { Effect of individual item on OHRQoL: } \\
\text { Eating and enjoying food: } \\
\text { Cases were } 13.4 \text { times ( } 95 \% \text { CI }=3.0-61.0 \text { ) more likely to report an impact for 'eating and enjoying } \\
\text { food' than children with no traumatic dental injury. } \\
\text { Speaking and pronouncing clearly: } \\
\text { This item had the least impact for both case and control groups. } \\
\text { Cleaning your mouth: } \\
\text { The impact for 'cleaning teeth' was statistically and significantly associated with the group of } \\
\text { children with untreated fractured teeth. Children with fractured teeth were more likely to report } \\
\text { an impact for this item than children without TDI. } \\
\text { Smiling, laughing, and showing teeth without embarrassment: The most prevalent OIDP impact } \\
\text { was seen in this item for both cases and controls. Children with fractured teeth were more likely } \\
\text { to report an impact for this item than children without a TDI. The appearance of untreated } \\
\text { fractured teeth was the main factor affecting this OIDP item. } \\
\text { Maintaining emotional state without being irritable: The impact of this item on OIDP was } \\
\text { statistically significant. Cases were } 11.8 \text { times more likely to report an impact for this item than } \\
\text { controls. The appearance of untreated fractured teeth was the main factor affecting this OIDP item } \\
\text { Contact with people: There was a statistically significant association between 'enjoying contact } \\
\text { with people' and the presence of fractured teeth. Cases were } 10.0 \text { times more likely to report an } \\
\text { impact for the item 'enjoying contact with people' when compared to controls. } \\
\text { Overall OIDP score: Children with fractured teeth were } 20 \text { times more likely to report any impact } \\
\text { on their daily living than children with no traumatic dental injury. This shows that children with } \\
\text { fractured teeth had significantly higher OIDP scores than those without TDI. }\end{array}$} \\
\hline & $\begin{array}{c}\text { Eating and } \\
\text { enjoying } \\
\text { your food } \\
\text { OIDP }=0 \\
\text { OIDP >0 }\end{array}$ & $\begin{array}{l}55(80.9) \\
13(19.1)\end{array}$ & $\begin{array}{c}134(98.5) \\
2(1.5)\end{array}$ & $\begin{array}{c}1 \\
13.0(2.9-57.6) \\
p<0.01\end{array}$ & $\begin{array}{c}1 \\
13.4(3.0-61.0) \\
p<0.01\end{array}$ & \\
\hline & $\begin{array}{l}\text { Speaking and } \\
\text { pronouncing } \\
\text { clearly } \\
\text { OIDP }=0 \\
\text { OIDP }>0\end{array}$ & $\begin{array}{c}64(94.1) \\
4(5.9)\end{array}$ & $\begin{array}{c}135(99.3) \\
1(0.7)\end{array}$ & $\begin{array}{c}1 \\
8.0(0.9-71.6)\end{array}$ & $\begin{array}{c}1 \\
8.0(0.9-75.0)\end{array}$ & \\
\hline & $\begin{array}{c}\text { Cleaning } \\
\text { your mouth } \\
\text { OIDP }=0 \\
\text { OIDP }>0\end{array}$ & $\begin{array}{l}58(85.3) \\
10(7.14)\end{array}$ & $\begin{array}{c}129(94.9) \\
7(5.1)\end{array}$ & $\begin{array}{c}1 \\
4.0(1.2-13.1) \\
p<0.05\end{array}$ & $\begin{array}{c}1 \\
3.9(1.2-13.0) \\
p<0.05\end{array}$ & \\
\hline & $\begin{array}{c}\text { Smiling, } \\
\text { laughing, } \\
\text { and showing } \\
\text { our teeth } \\
\text { without em- } \\
\text { barrassment } \\
\text { OIDP }=0 \\
\text { OIDP >0 }\end{array}$ & $\begin{array}{l}30(44.1) \\
38(55.9)\end{array}$ & $\begin{array}{l}118(86.8) \\
18(13.2)\end{array}$ & $\begin{array}{c}1 \\
8.6(3.8-19.5) \\
p<0.001\end{array}$ & $\begin{array}{c}1 \\
15.7(5.0-44.6) \\
p<0.001\end{array}$ & \\
\hline & $\begin{array}{l}\text { Maintaining } \\
\text { your emotional } \\
\text { state without } \\
\text { being irritatble } \\
\text { OIDP }=0 \\
\text { OIDP }>0\end{array}$ & $\begin{array}{l}45(66.2) \\
23(33.8)\end{array}$ & $\begin{array}{c}129(94.9) \\
7(5.1)\end{array}$ & $\begin{array}{c}1 \\
10.4(3.6-30.3) \\
p<0.001\end{array}$ & $\begin{array}{c}1 \\
11.8(3.9-35.5) \\
p<0.001\end{array}$ & \\
\hline & $\begin{array}{c}\text { Contact with } \\
\text { people } \\
\text { OIDP }=0 \\
\text { OIDP >0 }\end{array}$ & $\begin{array}{l}58(85.3) \\
10(14.7)\end{array}$ & $\begin{array}{c}134(98.5) \\
2(1.5)\end{array}$ & $\begin{array}{c}1 \\
10.0(2.2-45.6) \\
p<0.01\end{array}$ & $\begin{array}{c}1 \\
10.0(2.1-47.2) \\
p<0.001\end{array}$ & \\
\hline & $\begin{array}{c}\text { Overall OIDP } \\
\text { OIDP }=0 \\
\text { OIDP }>0\end{array}$ & $\begin{array}{l}23(33.8) \\
45(66.2)\end{array}$ & $\begin{array}{l}116(85.3) \\
20(14.7)\end{array}$ & $\begin{array}{c}1 \\
10.2(4.6-22.8) \\
p<0.001\end{array}$ & $\begin{array}{c}1 \\
20.0(7.0-57.7) \\
p<0.001\end{array}$ & \\
\hline
\end{tabular}


Table 4. Cont.

\begin{tabular}{|c|c|c|c|c|}
\hline Author/Year & & alue of Each D & & Results \\
\hline \multirow{10}{*}{$\begin{array}{c}\text { Basavaraj } \\
\text { et al. } \\
\text { (2014) [28] }\end{array}$} & OIDP & $\begin{array}{l}\text { Impact score } \\
\text { mean (SD) }\end{array}$ & OR $(95 \% \mathrm{CI})$ & \multirow{10}{*}{$\begin{array}{l}\text { Effect of gender on oral impact: There was no association between oral impacts and gender. } \\
\text { Effect of age on OIDP: There was a significant difference among the age groups, with younger age } \\
\text { groups reporting more trauma. } \\
\text { Effect of individual item on OIDP: Eating: Children with TDI demonstrated significant impacts on } \\
\text { eating }(\mathrm{OR}=11.0) \text {. Difficulty with eating due to oral problems was the most common impact } \\
(72.9 \%) \text { and led to more severe oral impacts on children's quality of life than impacts on other } \\
\text { performances. } \\
\text { Children with TDI demonstrated significant impacts on cleaning teeth }(\mathrm{OR}=3.5) \text {, emotional } \\
\text { status (OR }=10.0) \text {, smiling }(\mathrm{OR}=15.2) \text {, and contact }(\mathrm{OR}=13.1) \text {. } \\
\text { Children with TDI were less likely to have an impact on relaxing }(\mathrm{OR}=0.6) \text {. } \\
\text { Overall impact: Significant association was observed for oral impacts on daily performance with } \\
\text { TDI at } p \text {-value } \leq 0.05 \text {. Overall, } 60 \% \text { of children reported at least one impact on quality of life } \\
\text { attributed to oral health in the last three months. }\end{array}$} \\
\hline & Overall impacts(\%) & $2.49(3.92)$ & & \\
\hline & Eating & $1.60(4.49)$ & $\begin{array}{c}11.0(10.7-9.11) \\
p \leq 0.05\end{array}$ & \\
\hline & Speaking & $0.10(0.71)$ & $7.0(2.1-55.2)$ & \\
\hline & Cleaning teeth & $0.87(3.07)$ & $\begin{array}{c}3.5(2.4-16.2) \\
\quad p \leq 0.05\end{array}$ & \\
\hline & Relaxing & $0.39(2.65)$ & $0.6(0.1-0.9)$ & \\
\hline & Emotion & $0.61(2.92)$ & $\begin{array}{c}10.0(1.2-18.2) \\
p \leq 0.05\end{array}$ & \\
\hline & Smiling & $1.31(4.22)$ & $\begin{array}{c}15.2(11.1-24.2) \\
p \leq 0.05\end{array}$ & \\
\hline & Study & $0.06(0.59)$ & $0.8(0.2-1.7)$ & \\
\hline & Contact & $0.51(2.13)$ & $\begin{array}{c}13.1(9.4-19.2) \\
p \leq 0.05\end{array}$ & \\
\hline
\end{tabular}


Table 4. Cont.

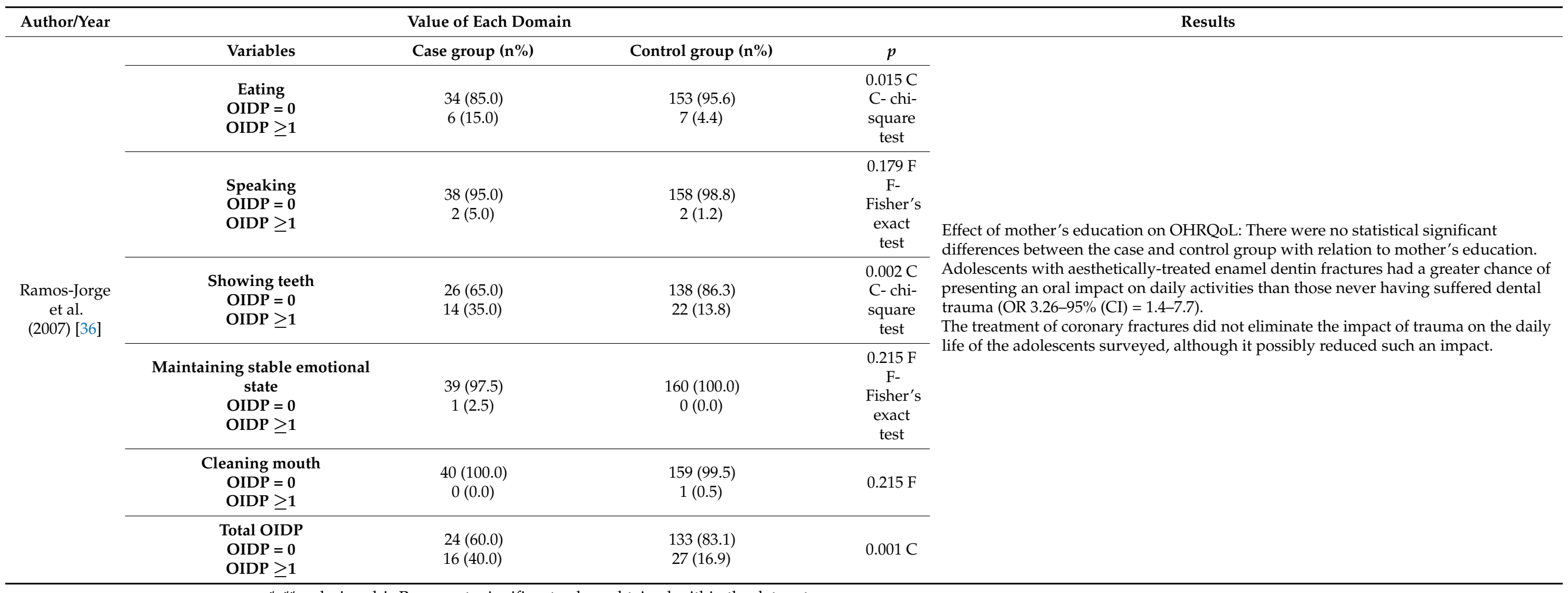

$*, * *, a, b,+$ and $\ddagger$ : Represents significant values obtained within the data set. 


\section{Discussion}

This review included 25 studies (Table 1) that assessed the impact of a traumatic dental injury of permanent teeth on the oral health-related quality of life (OHRQoL) in children and adolescent patients. The subjective evaluation of OHRQoL "reflects people's comfort when eating, sleeping, and engaging in social interaction; their self-esteem; and their satisfaction concerning their oral health" [44]. With a growing emphasis on health promotion and illness prevention in health policy, OHRQoL has evolved to include positive and negative assessments of oral health and health outcomes [45]. As a result, oral health assessments might reveal both negative and positive effects on self-esteem and well-being.

We assessed the quality of the studies using the Q-SSP tool [20]. This tool helps researchers to perform a uniform quality assessment of survey studies in psychology across the globe. Using tools such as the Q-SSP checklist to evaluate study quality will raise the profile of reporting standards and drive greater precision in reporting the survey study methods. Researchers can use the tool to assess the quality of studies as an inclusion criterion in systematic reviews and meta-analyses. In addition, the tool may be used by professional clinicians, physicians, and practitioners wishing to evaluate the quality of psychological evidence that may inform their practice. It may also be helpful for educators to illustrate issues relating to study quality in research method courses.

Most of the studies used for evaluation of OHRQoL of patients with a TDI or a TDI with treatment needs were of acceptable quality, except for four studies [22,25,31,41], which had questionable quality (Figure 2). Therefore, the conclusion of these articles will be taken with caution. Seven tools were used in this systematic review. These were the P-CPQ tool, $\mathrm{P}-\mathrm{CPQ}+\mathrm{CPQ}(8-10),(11-14)+\mathrm{FIS}, \mathrm{CPQ}(8-10), \mathrm{CPQ}(11-14)-16$ short form and ten short forms, the Brazilian version of FIS, Oral Health Impact Profile (OHIP-14), Child-OIDP, and OIDP.

The most common tool used for the assessment of OHRQoL was CPQ(11-14) in 10 studies $[15,25-27,29,31,33,41-43]$. All questionnaire variations evaluated the impact of oral and orofacial conditions in children at symptomatic, functional, emotional, and social levels. To date, the CPQ has been translated, validated, and adapted to suit several languages and socio-cultural contexts, demonstrating its applicability and perfect psychometric properties on numerous clinical and epidemiological occasions [46].

The Child-OIDP was the second-most used tool for assessing the OHRQoL in children in five studies [9,28,34-36]. Child-OIDP and CPQ (11-14) differ in their aim and theoretical framework. The Child-OIDP has an advantage over the CPQ and other OHRQoL measures, as it specifies the different clinical causes of each oral impact $[47,48]$. The Child-OIDP has a greater sensitivity than $\mathrm{CPQ}$ in identifying the impact on the quality of life of schoolchildren with a TDI.

Due to much heterogeneity in the data, it was not possible to perform a meta-analysis for all the parameters used in studies; therefore, qualitative assessment was conducted. However, meta-analysis was possible for only two studies using the Child OIDP tool.

Most of the studies $[24,25,29,31-33,35]$ that evaluated patients with TDI and no TDI revealed that patients with TDI have a negative impact on the OHRQoL, whereas in other studies $[37,38,41]$ where TDI patients were compared based on whether they received treatment or not, they revealed that patients who received treatment had a positive impact on OHRQoL.

All the tools that analyzed the OHRQoL assessed the patient and their parents in various parameters, including sociodemographic status, economic status, parent's education, gender, age group, and type of schooling. All these factors affected the OHRQoL of children, except for the type of schooling.

It was expected that a higher prevalence of TDI is in males compared to females [26], due to males being more engaged in sports and recreational activities involving physical contact. However, due to a change in social roles, adolescent females also pose an equal risk of TDI, as there is an increase in their participation in sports. Females are currently exposed to the same etiological factors. However, variations between genders may oc- 
cur due to environmental, cultural, and behavioral factors, which are determinants of a stronger or weaker association between TDI and gender [49-51]. However, although four studies $[25,26,28,31]$ out of eight [23-28,31,41] showed no association between gender and its impact on OHRQoL, another three studies [23,24,41] did imply that there is a strong association of TDI impact on OHRQoL among females compared to males. This outcome can be due to more significant aesthetic concerns of females than males, which negatively impacts their appearance [52-54].

All the studies expressed that the child perception of TDI impact on the OHRQoL does not change with age. Children between the age group of 8-10 years have criteria similar to those of children between 11-14 years regarding the self-perception of body image. To evaluate their appearance, children compare themselves to others of their age, and the judgment of peers exerts an influence on the development of self-esteem [55].

However, parents of the older children perceived a more significant reduction in their QoL than the parents of the 8-10-year-old group with TDI. This more remarkable impact on parents of the older children may be due to their children's growing independence suddenly being reversed by the need for parental intervention and supervision [40].

Seven out of 10 studies evaluated another parameter that negatively impacts TDI associated OHRQoL: the family's socioeconomic status of $[9,21,24,27,29,30,34]$. Due to their existing living conditions, which are usually less privileged and peripheries of urban areas, where facilities and quality healthcare are questionable, children are often exposed to unsafe environments. These underdeveloped areas increase accidents due to poorly-designed urban projects and neglected public spaces [56-58].

Even if parents wished to have the child's condition treated, they cannot afford dental care at both private and public centers [59].

Parents' education also impacts the OHRQoL of children with a TDI. Six studies $[9,21,24,29,30,34]$ out of nine reported that fewer years of parents' education level showed a negative impact on OHRQoL of children. The majority of parents in these studies had low education status. This reflects their lack of information, perception, and treatment needs associated with TDI and negatively influenced the child's health behaviors.

Children with severe TDI also impacted the family regarding parental/family activity, parental emotions, family conflict, and financial burden $[29,38,40]$. Severe types of trauma more often affected the daily life of parents/caregivers. Parents/caregivers of adolescents with fractures involving the dentine or dentine/pulp reported more negative impact on parental/family activities than those with less severe TDI, such as enamel fracture [29]. A TDI is an unexpected event. More severe cases nearly always require urgent care and multiple searches for dental treatment, resulting in parents missing work and spending extra time taking care of their children. From these studies, it can be concluded that severe trauma not only affects the child in question, but it also affects the family.

Individual domains such as oral symptoms (OS), emotional well-being (EWB), social well-being (SWB), and functional limitations (FL) were mainly analyzed by different studies. These domains are individuals perception of TDI and their overall impact on OHRQoL. It was pretty evident that the most affected domains were EWB, OS, and FL. TDI was significantly affected by these three domains. The "emotional well-being" domain contains questions related to emotions such as sad, embarrassed, worried, upset, frustrated, angry, and concerned about what others think. Physical appearance and attractiveness play an essential role in social interactions and psychological well-being among adolescents between the ages of 11 and 14 [60]. Peer relationships are an important factor in an individual's quality of life at this age [61]. Because the mouth is such a significant predictor of face attractiveness, any changes in dental features can have a detrimental or good impact on the quality of life [62]. The 'oral symptoms' domain contains questions about pain, wounds, mouth sores, bad breath, and food remains trapped in the mouth [38]. As this domain contains questionnaires related to lips, teeth, and jaws, the scores were high in this domain and thus affected the OHRQoL. The "functional limitations" domain contains questions 
related to difficulty with eating, biting, speaking, and sleeping. The overall cumulative effect of the individual domain significantly affected the TDI-associated OHRQoL.

Children with fractured teeth experienced more impacts on their daily living than children with no traumatic dental injury. Their actual daily basic performances such as 'eating and enjoying food', 'cleaning teeth', 'smiling, laughing, and showing teeth without embarrassment', 'maintaining usual emotional state without being irritable', and 'enjoying contact with people' significantly affected the OHRQoL when compared to children with no dental trauma experience [35].

It was observed that, after receiving the treatment of TDI, children were able to enjoy foods, smile, show one's teeth without embarrassment, and socialize. Thus, dental treatment following a TDI is an important prevention strategy regarding biological and socio-psychological impacts [9]. Treatment of TDI improved the OHRQoL considerably.

\section{Conclusions}

Traumatic injuries to permanent dentition affect both a child and their caregivers or parents. These injuries affect both genders; however, adolescent girls tend to have a more negative impact on their OHRQoL than boys. A TDI and its severity significantly affect children and their families social and emotional well-being. Parents' education and socioeconomic status play a significant role in providing care and treatment of TDIs in children. Treatment of TDIs improve the aesthetic and functional aspects of dentition and enhance the OHRQoL. Since the majority of studies used well-validated questionnaire tools and were of high quality, it can be concluded that the TDI impact on the OHRQoL is significant.

Author Contributions: Conceptualization, L.M. and P.D.; methodology, L.M.; software, B.L.; validation, L.M., D.J. and P.D.; formal analysis, L.M.; investigation, S.G.; resources, S.P.; data curation, P.D.; writing—original draft preparation, L.M.; writing—review and editing, B.L.; visualization, L.M.; supervision, B.L.; project administration, L.M.; funding acquisition, B.L. All authors have read and agreed to the published version of the manuscript.

Funding: This research received no external funding.

Institutional Review Board Statement: Not applicable.

Informed Consent Statement: Not applicable.

Data Availability Statement: Not applicable.

Acknowledgments: We thank the Institute of Dental Sciences, Cochrane India Network for helping us with the resources required for the study.

Conflicts of Interest: The authors declare no conflict of interest.

\section{Abbreviations}

$\begin{array}{ll}\text { CFED } & \text { crown fracture involving enamel and dentin } \\ \text { COHQoL } & \text { Child Oral Health Quality of Life } \\ \text { CPQ } & \text { Child Perceptions Questionnaire } \\ \text { Child-OIDP } & \text { Child-Oral Impact on Daily Performances } \\ \text { FIS } & \text { Family Impact Scale in three articles } \\ \text { ISF } & \text { Impact Short Form } \\ \text { OIDP } & \text { Oral Impact on Daily Performances } \\ \text { OHIP } & \text { Oral Health Impact Profile } \\ \text { OHRQoL } & \text { Oral Health-Related Quality of Life } \\ \text { P-CPQ } & \text { Parental-Caregivers Perceptions Questionnaire } \\ \text { Q-SSP } & \text { Quality assessment checklist for survey studies in psychology } \\ \text { TDI } & \text { Traumatic Dental Inury }\end{array}$




\section{Appendix A}

full texts.

Table A1 presents a list of the studies excluded from the review after reading their

Table A1. List of excluded studies after reading the full text.

\begin{tabular}{|c|c|c|}
\hline Author & Title & Reason for Exclusion \\
\hline Flores et al. [63] & $\begin{array}{l}\text { How Does Orofacial Trauma in Children Affect the } \\
\text { Developing Dentition? Long-term Treatment and } \\
\text { Associated Complications }\end{array}$ & $\begin{array}{l}\text { The OHRQoL was not checked. It is a } \\
\text { treatment-based study. }\end{array}$ \\
\hline Gomes et al. [64] & $\begin{array}{l}\text { Oral Problems and Self-Confidence in } \\
\text { Preschool Children }\end{array}$ & This study was conducted in primary dentition. \\
\hline Cengiz et al. [65] & Impact of seizure-related injuries on quality of life & TDI has not been evaluated. \\
\hline Sakaryali et al. [66] & $\begin{array}{l}\text { Evaluation of the Impact of Early Childhood Caries, } \\
\text { Traumatic Dental Injury, and Malocclusion on Oral } \\
\text { Health-Related Quality of Life for Turkish Preschool } \\
\text { Children and Families }\end{array}$ & The study was conducted in primary dentition. \\
\hline Soares et al. [10] & $\begin{array}{l}\text { The impact of crown fracture in the permanent } \\
\text { dentition on children's quality of life }\end{array}$ & $\begin{array}{l}\text { This article is not published in any journal and is } \\
\text { in press. }\end{array}$ \\
\hline Gonçalves et al. [67] & $\begin{array}{l}\text { Impact of dental trauma and esthetic impairment on } \\
\text { the quality of life of preschool children. }\end{array}$ & The study was conducted in primary dentition. \\
\hline Braimah et al. [68] & $\begin{array}{l}\text { Self-esteem following maxillofacial and orthopedic } \\
\text { injuries: preliminary observations in } \\
\text { sub-Saharan Africans }\end{array}$ & This study did not include permanent dentition. \\
\hline Ramos-Jorge et al. [69] & $\begin{array}{l}\text { Parents' recognition of dental trauma in } \\
\text { their children }\end{array}$ & This study was conducted in primary dentition. \\
\hline Ramos-Jorge et al. [70] & $\begin{array}{l}\text { Effect of dark discolouration and enamel/dentine } \\
\text { fracture on the oral health-related quality of life of } \\
\text { pre-schoolers }\end{array}$ & This study was conducted in primary dentition. \\
\hline Granville-Garcia et al. [71] & $\begin{array}{l}\text { Parental influence on children's answers to an } \\
\text { oral-health-related quality of life questionnaire }\end{array}$ & This study was conducted in primary dentition. \\
\hline Vieira-Andrade et al. [72] & $\begin{array}{l}\text { Impact of traumatic dental injury on the quality of } \\
\text { life of young children: a case-control study }\end{array}$ & This study was conducted in primary dentition. \\
\hline Aldrigui et al. [73] & $\begin{array}{l}\text { Impact of traumatic dental injuries and } \\
\text { malocclusions on quality of life of young children }\end{array}$ & This study was conducted in primary dentition. \\
\hline Firmino et al. [74] & $\begin{array}{l}\text { Impact of oral health problems on the quality of life } \\
\text { of preschool children: a case-control study }\end{array}$ & This study was conducted in primary dentition. \\
\hline Barbosa Neves et al. [75] & $\begin{array}{l}\text { Perception of parents and self-reports of children } \\
\text { regarding the impact of traumatic dental injury on } \\
\text { quality of life }\end{array}$ & This study was conducted in primary dentition. \\
\hline Siqueira et al. [76] & $\begin{array}{l}\text { Impact of Traumatic Dental Injury on the Quality of } \\
\text { Life of Brazilian Preschool Children }\end{array}$ & This study was conducted in primary dentition. \\
\hline Viegas et al. [77] & $\begin{array}{l}\text { Influence of traumatic dental injury on quality of life } \\
\text { of Brazilian preschool children and their families }\end{array}$ & This study was conducted in primary dentition. \\
\hline Gomes et al. [78] & $\begin{array}{c}\text { Impact of oral health conditions on the quality of life } \\
\text { of preschool children and their families: a } \\
\text { cross-sectional study }\end{array}$ & This study was conducted in primary dentition. \\
\hline Abanto et al. [79] & $\begin{array}{l}\text { Impact of traumatic dental injuries and } \\
\text { malocclusions on quality of life of preschool children: } \\
\text { a population-based study }\end{array}$ & This study was conducted in primary dentition. \\
\hline Abanto et al. [80] & $\begin{array}{l}\text { The impact of dental caries and trauma in children } \\
\text { on family quality of life }\end{array}$ & This study was conducted in primary dentition. \\
\hline Abanto et al. [81] & $\begin{array}{c}\text { Impact of dental caries and trauma on quality of life } \\
\text { among 5- to 6-year-old children: perceptions of } \\
\text { parents and children }\end{array}$ & This study was conducted in primary dentition. \\
\hline
\end{tabular}


Table A1. Cont.

\begin{tabular}{ccc}
\hline Author & Title & Reason for Exclusion \\
\hline Feldens et al. [82] & $\begin{array}{c}\text { Enamel fracture in the primary dentition has no } \\
\text { impact on children's quality of life: implications for } \\
\text { clinicians and researchers }\end{array}$ & $\begin{array}{c}\text { This study was conducted in primary dentition. } \\
\text { Scarpelli et al. [83] }\end{array}$ \\
\hline Viegas et al. [84] & $\begin{array}{c}\text { Impact of Traumatic Dental Injury on Quality of Life } \\
\text { Among Brazilian Preschool Children and } \\
\text { Their Families }\end{array}$ & This study was conducted in primary dentition. \\
\hline Kramer et al. [85] & $\begin{array}{c}\text { Exploring the impact of oral diseases and disorders } \\
\text { on quality of life of preschool children }\end{array}$ & This study was conducted in primary dentition. \\
\hline Borges et al. [86] & $\begin{array}{c}\text { Relationship between overweight/obesity in the first } \\
\text { year of age and traumatic dental injuries in early } \\
\text { childhood: Findings from a birth cohort study }\end{array}$ & This study was conducted in primary dentition. \\
\hline
\end{tabular}

\section{References}

1. Goursand, D.; Paiva, S.M.; Zarzar, P.M.; Pordeus, I.A.; Grochowski, R.; Allison, P.J. Measuring parental-caregiver perceptions of child oral health-related quality of life: Psychometric properties of the Brazilian version of the P-CPQ. Braz. Dent. J. 2009, 20, 169-174. [CrossRef] [PubMed]

2. Pahel, B.T.; Rozier, R.G.; Slade, G.D. Parental perceptions of children's oral health: The Early Childhood Oral Health Impact Scale (ECOHIS. Health Qual. Life Outcomes 2007, 5, 6. [CrossRef] [PubMed]

3. Sheiham, A.; Steele, J.G.; Marcenes, W.; Tsakos, G.; Finch, S.; Walls, A.W.G. Prevalence of impacts of dental and oral disorders and their effects on eating among older people; a national survey in Great Britain. Community Dent. Oral Epidemiol. 2001, 29, 195-203. [CrossRef] [PubMed]

4. Sgan-Cohen, H.D.; Megnagi, G.; Jacobi, Y. Dental trauma and its association with anatomic, behavioral, and social variables among fifth and sixth grade schoolchildren in Jerusalem. Community Dent. Oral Epidemiol. 2005, 33, 174-180. [CrossRef]

5. Cardoso, M.; De Carvalho Rocha, M.J. Traumatized Primary Teeth in Children Assisted at the Federal University of Santa Catarina, Brazil. Dent. Traumatol. 2002, 18, 129-133. [CrossRef]

6. Şaroğlu, I.; Sönmez, H. The prevalence of traumatic injuries treated in the pedodontic clinic of Ankara University, Turkey, during 18 months. Dent. Traumatol. 2002, 18, 299-303. [CrossRef]

7. Eiser, C.; Morse, R. The measurement of quality of life in children: Past and future perspectives. J. Dev. Behav. Pediatr. JDBP 2001, 22, 248-256. [CrossRef]

8. Allison, P.J.; Locker, D.; Feine, J.S. Quality of life: A dynamic construct. Soc. Sci. Med. 1982, 45, 221-230. [CrossRef]

9. Ramos-Jorge, J.; Paiva, S.M.; Tataounoff, J.; Pordeus, I.A.; Marques, L.S.; Ramos-Jorge, M.L. Impact of treated/untreated traumatic dental injuries on quality of life among Brazilian schoolchildren. Dent. Traumatol. 2014, 30, 27-31. [CrossRef]

10. Soares, J.P.; Barasuol, J.C.; Torres, F.M.; Giacomin, A.; Gonçalves, B.M.; Klein, D.; Borgatto, A.F.; Ramos-Jorge, M.L.; Cardoso, M.; Bolan, M. The impact of crown fracture in the permanent dentition on children's quality of life. Dent. Traumatol. 2018, 34, 158-163. [CrossRef]

11. Marcenes, W.; Beiruti, N.; Tayfour, D.; Issa, S. Epidemiology of traumatic injuries to the permanent incisors of 9-12-year-old schoolchildren in Damascus, Syria. Endod Dent. Traumatol. 1999, 15, 117-123. [CrossRef] [PubMed]

12. Granville-Garcia, A.F.; de Menezes, V.A.; de Lira, P.I.C. Dental trauma and associated factors in Brazilian preschoolers. Dent. Traumatol. 2006, 22, 318-322. [CrossRef] [PubMed]

13. Årtun, J.; Behbehani, F.; Al-Jame, B.; Kerosuo, H. Incisor trauma in an adolescent Arab population: Prevalence, severity, and occlusal risk factors. Am. J. Orthod. Dentofac. Orthop. 2005, 128, 347-352. [CrossRef] [PubMed]

14. Traebert, J.; Bittencourt, D.D.; Peres, K.G.; Peres, M.A.; de Lacerda, J.T.; Marcenes, W. Aetiology and rates of treatment of traumatic dental injuries among 12-year-old school children in a town in southern Brazil. Dent. Traumatol. 2006, 22, 173-178. [CrossRef]

15. Bendo, C.B.; Paiva, S.M.; Torres, C.S.; Oliveira, A.C.; Goursand, D.; Pordeus, I.A. Association between treated/untreated traumatic dental injuries and impact on quality of life of Brazilian schoolchildren. Health Qual. Life Outcomes 2010, 8, 114. [CrossRef]

16. Noori, A.J.; Al-Obaidi, W.A. Traumatic dental injuries among primary school children in Sulaimani city, Iraq. Dent. Traumatol. 2009, 25, 442-446. [CrossRef]

17. Fakhruddin, K.S.; Lawrence, H.P.; Kenny, D.J.; Locker, D. Etiology and environment of dental injuries in 12- to 14-year-old Ontario schoolchildren. Dent. Traumatol. 2008, 24, 305-308. [CrossRef]

18. Zaleckiene, V.; Peciuliene, V.; Brukiene, V.; Drukteinis, S. Traumatic dental injuries: Etiology, prevalence and possible outcomes. Stomatologija 2014, 16, 7-14.

19. Shamseer, L.; Moher, D.; Clarke, M.; Ghersi, D.; Liberati, A.; Petticrew, M.; Shekelle, P.; Stewart, L.A. Preferred reporting items for systematic review and meta-analysis protocols (PRISMA-P) 2015: Elaboration and explanation. BMJ 2015, 349, g7647. [CrossRef] 
20. Protogerou, C.; Hagger, M.S. A checklist to assess the quality of survey studies in psychology. Methods Psychol. $2020,3,100031$. [CrossRef]

21. Díaz, S.; Vélez, M.P.; Martínez, L.M.; Ramos, K.; Boneckër, M.; Martins Paiva, S.; Abanto, J. Parental perceptions of impact of oral disorders on Colombian schoolchildren's oral healthrelated quality of life. Acta. Odontol. Latinoam. 2018, 31, 82-90. [PubMed]

22. Martins, M.T.; Sardenberg, F.; Bendo, C.B.; Vale, M.P.; Paiva, S.M.; Pordeus, I.A. Dental caries are more likely to impact on children's quality of life than malocclusion or traumatic dental injuries. Eur. J. Paediatr. Dent. 2018, 19, 194-198. [PubMed]

23. Freire-Maia, F.B.; Auad, S.M.; Abreu, M.H.N.G.D.; Sardenberg, F.; Martins, M.T.; Paiva, S.M.; Pordeus, I.A.; Vale, M.P. Oral Health-Related Quality of Life and Traumatic Dental Injuries in Young Permanent Incisors in Brazilian Schoolchildren: A Multilevel Approach. PLoS ONE 2015, 10, e0135369. [CrossRef] [PubMed]

24. Sardenberg, F.; Cavalcante-Leão, B.L.; Todero, S.R.B.; Ferreira, F.M.; Rebellato, N.L.B.; Fraiz, F.C. A population-based study on the impact of orofacial dysfunction on oral health-related quality of life among Brazilian schoolchildren. Acta Odontol. Scand. 2017, 75, 173-178. [CrossRef]

25. Silva-Oliveira, F.; Goursand, D.; Ferreira, R.C.; Paiva, P.C.P.; Paiva, H.N.; Ferreira, E.F.; Zarzar, P.M. Traumatic dental injuries in Brazilian children and oral health-related quality of life. Dent. Traumatol. 2018, 34, 28-35. [CrossRef]

26. Rajab, L.D.; Abu Al Huda, D. Impact of treated and untreated traumatic dental injuries on oral health-related quality of life among 12-year-old schoolchildren in Amman. Dent. Traumatol. 2019, 35, 153-162. [CrossRef]

27. Damé-Teixeira, N.; Alves, L.S.; Ardenghi, T.M.; Susin, C.; Maltz, M. Traumatic dental injury with treatment needs negatively affects the quality of life of Brazilian schoolchildren. Int. J. Paediatr. Dent. 2013, 23, 266-273. [CrossRef]

28. Basavaraj, P.; Sunil, M.K.; Nagarajappa, R.; Ashish, S.; Ramesh, G. Correlation between oral health and Child-OIDP index in 12and 15-year-old children from Modinagar, India. Asia Pac. J. Public Health 2014, 26, 390-400. [CrossRef]

29. Bendo, C.B.; Paiva, S.M.; Abreu, M.H.; Figueiredo, L.D.; Vale, M.P. Impact of traumatic dental injuries among adolescents on family's quality of life: A population-based study. Int. J. Paediatr. Dent. 2014, 24, 387-396. [CrossRef]

30. Bomfim, R.A.; Herrera, D.R.; De-Carli, A.D. Oral health-related quality of life and risk factors associated with traumatic dental injuries in Brazilian children: A multilevel approach. Dent. Traumatol. 2017, 33, 358-368. [CrossRef]

31. Bendo, C.B.; Paiva, S.M.; Varni, J.W.; Vale, M.P. Oral health-related quality of life and traumatic dental injuries in Brazilian adolescents. Community Dent. Oral Epidemiol. 2014, 42, 216-223. [CrossRef] [PubMed]

32. Antunes, L.S.; Debossan, P.F.; Bohrer, L.S.; Abreu, F.V.; Quintanilha, L.E.L.P.; Antunes, L.A.A. Impact of traumatic dental injury on the quality-of-life of children and adolescents: A case-control study. Acta Odontol. Scand. 2013, 71, 1123-1128. [CrossRef] [PubMed]

33. Fakhruddin, K.S.; Lawrence, H.P.; Kenny, D.J.; Locker, D. Impact of treated and untreated dental injuries on the quality of life of Ontario school children. Dent. Traumatol. 2008, 24, 309-313. [CrossRef] [PubMed]

34. Thelen, D.S.; Trovik, T.A.; Bårdsen, A. Impact of traumatic dental injuries with unmet treatment need on daily life among Albanian adolescents: A case-control study. Dent. Traumatol. 2011, 27, 88-94. [CrossRef] [PubMed]

35. Ilma de Souza Cortes, M.; Marcenes, W.; Sheiham, A. Impact of traumatic injuries to the permanent teeth on the oral health-related quality of life in 12-14-year-old children. Community Dent. Oral Epidemiol. 2002, 30, 193-198. [CrossRef]

36. Ramos-Jorge, M.L.; Bosco, V.L.; Peres, M.A.; Nunes, A.C.G.P. The impact of treatment of dental trauma on the quality of life of adolescents? A case-control study in southern Brazil. Dent. Traumatol. 2007, 23, 114-119. [CrossRef]

37. Antunes, L.A.A.; Luiz, R.R.; Leão, A.T.T.; Maia, L.C. Initial assessment of responsiveness of the P-CPQ (Brazilian Version) to describe the changes in quality of life after treatment for traumatic dental injury. Dent. Traumatol. 2012, 28, 256-262. [CrossRef]

38. Magno, M.B.; Jural, L.A.; Nogueira, A.D.V.; Lenzi, M.M.; Pithon, M.M.; Maia, L.C. Impact of crown fracture treatment on oral health-related quality of life of children, adolescents, and their families: A prospective clinical study. Int. J. Paediatr. Dent. 2019, 29, 86-93. [CrossRef]

39. Giannetti, L.; Murri, A.; Vecci, F.; Gatto, R. Dental avulsion: Therapeutic protocols and oral health-related quality of life. Eur. J. Paediatr. Dent. 2007, 2, 69-75.

40. Berger, T.D.; Kenny, D.J.; Casas, M.J.; Barrett, E.J.; Lawrence, H.P. Effects of severe dentoalveolar trauma on the quality-of-life of children and parents. Dent. Traumatol. 2009, 25, 462-469. [CrossRef]

41. Porritt, J.M.; Rodd, H.D.; Ruth Baker, S. Quality of life impacts following childhood dento-alveolar trauma. Dent. Traumatol. 2011, 27, 2-9. [CrossRef] [PubMed]

42. Locker, D. Disparities in oral health-related quality of life in a population of Canadian children. Community Dent. Oral Epidemiol. 2007, 35, 348-356. [CrossRef] [PubMed]

43. Traebert, J.; de Lacerda, J.T.; Foster Page, L.A.; Thomson, W.M.; Bortoluzzi, M.C. Impact of traumatic dental injuries on the quality of life of schoolchildren. Dent. Traumatol. 2012, 28, 423-428. [CrossRef] [PubMed]

44. U.S. Department of Health and Human Services. Oral Health in America: A Report of the Surgeon General; U.S. Department of Health and Human Services, National Institute of Dental and Craniofacial Research, National Institutes of Health: Rockville, MD, USA, 2000. Available online: https:/ / www.nidcr.nih.gov/sites/default/files/2017-10/hck1ocv.\%40www.surgeon.fullrpt.pdf (accessed on 2 March 2022).

45. Sischo, L.; Broder, H.L. Oral health-related quality of life: What, why, how, and future implications. J. Dent. Res. 2011, 90, 1264-1270. [CrossRef] 
46. Kavaliauskienè, A.; Šidlauskas, A.; Zaborskis, A. Modification and psychometric evaluation of the child perceptions questionnaire (CPQ11-14) in assessing oral health related quality of life among Lithuanian children. BMC Oral Health 2019, 19, 1. [CrossRef]

47. Gherunpong, S.; Tsakos, G.; Sheiham, A. Developing and evaluating an oral health-related quality of life index for children; the CHILD-OIDP. Community Dent. Health 2004, 21, 161-169.

48. Bernabé, E.; Oliveira, C.M.; Sheiham, A.; Tsakos, G. Comparison of the generic and condition-specific forms of the Oral Impacts on Daily Performances (OIDP) Index. J. Public Health Dent. 2009, 69, 176-181. [CrossRef]

49. Soriano, E.P.; Caldas, A.D., Jr.; Carvalho, M.V.; Amorim Filho, H.D. Prevalence and risk factors related to traumatic dental injuries in Brazilian schoolchildren. Dent. Traumatol. 2007, 23, 232-240. [CrossRef]

50. Glendor, U. Epidemiology of traumatic dental injuries-A 12 year review of the literature. Dent. Traumatol. 2008, 24, 603-611. [CrossRef]

51. De Carvalho Rocha, M.J.; Cardoso, M. Traumatized permanent teeth in Brazilian children assisted at the Federal University of Santa Catarina, Brazil. Dent. Traumatol. 2001, 17, 245-249. [CrossRef]

52. Leme, M.S.; de Souza Barbosa, T.; Gavião, M.B. Relationship among oral habits, orofacial function and oral health-related quality of life in children. Braz. Oral Res. 2013, 27, 272-282. [CrossRef] [PubMed]

53. Perez-Sayans, M.; Fernandez-Gonzalez, B.; Somoza-Martin, M.; Gándara-Rey, J.M.; García-García, A. Peri-Implant Bone Resorption around Implants Placed in Alveolar Bone Subjected to Distraction Osteogenesis. J. Oral Maxillofac. Surg. 2008, 66, 787-790. [CrossRef] [PubMed]

54. Barbosa, T.S.; Tureli, M.C.M.; Gavião, M.B.D. Validity and reliability of the Child Perceptions Questionnaires applied in Brazilian children. BMC Oral Health 2009, 9, 13. [CrossRef] [PubMed]

55. Shaw, W.C. The influence of children's dentofacial appearance on their social attractiveness as judged by peers and lay adults. Am. J. Orthod. 1981, 79, 399-415. [CrossRef]

56. Marcenes, W.; Murray, S. Social deprivation and traumatic dental injuries among 14-year-old schoolchildren in Newham, London. Dent. Traumatol. 2001, 17, 17-21. [CrossRef]

57. Cortes, M.I.S.; Marcenes, W.; Sheiham, A. Prevalence and correlates of traumatic injuries to the permanent teeth of school-children aged 9-14 years in Belo Horizonte, Brazil. Dent. Traumatol. 2001, 17, 22-26. [CrossRef]

58. Damé-Teixeira, N.; Alves, L.S.; Susin, C.; Maltz, M. Traumatic dental injury among 12-year-old South Brazilian schoolchildren: Prevalence, severity, and risk indicators. Dent. Traumatol. 2013, 29, 52-58. [CrossRef]

59. Bendo, C.B.; Paiva, S.M.; Oliveira, A.C.; Goursand, D.; Torres, C.S.; Pordeus, I.A. Prevalence and associated factors of traumatic dental injuries in Brazilian schoolchildren. J. Public Health Dent. 2010, 70, 313-318. [CrossRef]

60. Marques, L.S.; Ramos-Jorge, M.L.; Paiva, S.M.; Pordeus, I.A. Malocclusion: Esthetic impact and quality of life among Brazilian schoolchildren. Am. J. Orthod. Dentofac. Orthop. 2006, 129, 424-427. [CrossRef]

61. Jokovic, A.; Locker, D.; Guyatt, G. What do children's global ratings of oral health and well-being measure? Community Dent. Oral Epidemiol. 2005, 33, 205-211. [CrossRef]

62. Ahrari, F.; Heravi, F.; Rashed, R.; Zarrabi, M.J.; Setayesh, Y. Which Factors Affect Dental Esthetics and Smile Attractiveness in Orthodontically Treated Patients? J. Dent. Tehran Iran 2015, 12, 491.

63. Flores, M.T.; Onetto, J.E. How does orofacial trauma in children affect the developing dentition? Long-term treatment and associated complications. Dent. Traumatol. 2019, 35, 312-323. [CrossRef] [PubMed]

64. Gomes, M.C.; Perazzo, M.F.; Neves, É.T.; Martins, C.C.; Paiva, S.M.; Granville-Garcia, A.F. Oral problems and self-confidence in preschool children. Braz. Dent. J. 2017, 28, 523-530. [CrossRef] [PubMed]

65. Cengiz, O.; Atalar, A.Ç.; Tekin, B.; Bebek, N.; Baykan, B.; Gürses, C. Impact of seizure-related injuries on quality of life. Neurol. Sci. 2019, 40, 577-583. [CrossRef]

66. Sakaryali, D.; Bani, M.; Cinar, C.; Alacam, A. Evaluation of the impact of early childhood caries, traumatic dental injury, and malocclusion on oral health-Related quality of life for Turkish preschool children and families. Niger. J. Clin. Pract. 2019, 22, 817-823. [CrossRef] [PubMed]

67. Gonçalves, B.M.; Dias, L.F.; Da Silva Pereira, C.; Filho, M.X.P.; Konrath, A.C.; Da Silva Bolan, M.; Cardoso, M. Impact of dental trauma and esthetic impairment on the quality of life of preschool children. Rev. Paul. Pediatr. 2017, 35, 448-455. [CrossRef]

68. Braimah, R.O.; Ukpong, D.I.; Ndukwe, K.C.; Akinyoola, L. Self-esteem following maxillofacial and orthopedic injuries: Preliminary observations in sub-Saharan Africans. Oral Maxillofac. Surg. 2019, 23, 71-76. [CrossRef]

69. Ramos-Jorge, M.L.; Ramos-Jorge, J.; Mota-Veloso, I.; Oliva, K.J.; Zarzar, P.M.; Marques, L.S. Parents' recognition of dental trauma in their children. Dent. Traumatol. 2013, 29, 266-271. [CrossRef]

70. Ramos-Jorge, J.; Sá-Pinto, A.C.; Almeida Pordeus, I.; Martins Paiva, S.; Castro Martins, C.; Ramos-Jorge, M.L. Effect of dark discolouration and enamel/dentine fracture on the oral health-related quality of life of pre-schoolers. Eur. Arch. Paediatr. Dent. 2017, 18, 83-89. [CrossRef]

71. Granville-Garcia, A.F.; Gomes, M.C.; Dantas, L.R.; Dantas, L.R.; da Silva, B.R.C.; Perazzo, M.D.F.; Siqueira, M.B.L.D. Parental influence on children's answers to an oral-health-related quality of life questionnaire. Braz. Oral Res. 2016, 30, 1-8. [CrossRef]

72. Vieira-Andrade, R.G.; Siqueira, M.B.L.; Gomes, G.B.; D'Avila, S.; Pordeus, I.A.; Paiva, S.M.; Granville-Garcia, A.F. Impact of traumatic dental injury on the quality of life of young children: A case-control study. Int. Dent. J. 2015, 65, 261-268. [CrossRef] [PubMed] 
73. Aldrigui, J.M.; Abanto, J.; Carvalho, T.S.; Mendes, F.M.; Wanderley, M.T.; Bönecker, M.; Raggio, D.P. Impact of traumatic dental injuries and malocclusions on quality of life of young children. Health Qual. Life Outcomes 2011, 9, 78. [CrossRef] [PubMed]

74. Firmino, R.T.; Gomes, M.C.; Clementino, M.A.; Martins, C.C.; Paiva, S.M.; Granville-Garcia, A.F. Impact of oral health problems on the quality of life of preschool children: A case-control study. Int. J. Paediatr. Dent. 2016, 26, 242-249. [CrossRef] [PubMed]

75. Barbosa Neves, É.T.; Perazzo, M.F.; Gomes, M.C.; Martins, C.C.; Paiva, S.M.; Granville-Garcia, A.F. Perception of parents and self-reports of children regarding the impact of traumatic dental injury on quality of life. Dent. Traumatol. 2017, 33, 444-450. [CrossRef]

76. Siqueira, M.B.; Firmino, R.T.; Clementino, M.A.; Martins, C.C.; Granville-Garcia, A.F.; Paiva, S.M. Impact of traumatic dental injury on the quality of life of Brazilian preschool children. Int. J. Environ. Res. Public Health 2013, 10, 6422-6441. [CrossRef]

77. Viegas, C.M.; Paiva, S.M.; Carvalho, A.C.; Scarpelli, A.C.; Ferreira, F.M.; Pordeus, I.A. Influence of traumatic dental injury on quality of life of Brazilian preschool children and their families. Dent. Traumatol. 2014, 30, 338-347. [CrossRef]

78. Gomes, M.C.; Pinto-Sarmento, T.C.D.A.; Costa, E.M.M.D.B.; Martins, C.C.; Granville-Garcia, A.F.; Paiva, S.M. Impact of oral health conditions on the quality of life of preschool children and their families: A cross-sectional study. Health Qual. Life Outcomes 2014, 12, 55. [CrossRef]

79. Abanto, J.; Tello, G.; Bonini, G.C.; Oliveira, L.B.; Murakami, C.; Bönecker, M. Impact of traumatic dental injuries and malocclusions on quality of life of preschool children: A population-based study. Int. J. Paediatr. Dent. 2015, 25, 18-28. [CrossRef]

80. Abanto, J.; Paiva, S.M.; Raggio, D.P.; Celiberti, P.; Aldrigui, J.M.; Bönecker, M. The impact of dental caries and trauma in children on family quality of life. Community Dent. Oral Epidemiol. 2012, 40, 323-331. [CrossRef]

81. Abanto, J.; Tsakos, G.; Paiva, S.M.; Carvalho, T.S.; Raggio, D.P.; Bönecker, M. Impact of dental caries and trauma on quality of life among 5- to 6-year-old children: Perceptions of parents and children. Community Dent. Oral Epidemiol. 2014, 42, 385-394. [CrossRef]

82. Feldens, C.A.; Day, P.; Borges, T.S.; Feldens, E.G.; Kramer, P.F. Enamel fracture in the primary dentition has no impact on children's quality of life: Implications for clinicians and researchers. Dent. Traumatol. 2016, 32, 103-109. [CrossRef]

83. Scarpelli, A.C.; Paiva, S.M.; Viegas, C.M.; Carvalho, A.C.; Ferreira, F.M.; Pordeus, I.A. Oral health-related quality of life among Brazilian preschool children. Community Dent. Oral Epidemiol. 2013, 41, 336-344. [CrossRef] [PubMed]

84. Viegas, C.M.; Scarpelli, A.C.; Carvalho, A.C.; De Morais Ferreira, F.; Pordeus, I.A.; Paiva, S.M. Impact of traumatic dental injury on quality of life among brazilian preschool children and their families. Pediatr. Dent. 2012, 34, 300-306. [PubMed]

85. Kramer, P.F.; Feldens, C.A.; Helena Ferreira, S.; Bervian, J.; Rodrigues, P.H.; Peres, M.A. Exploring the impact of oral diseases and disorders on quality of life of preschool children. Community Dent. Oral Epidemiol. 2013, 41, 327-335. [CrossRef] [PubMed]

86. Borges, T.S.; Chaffee, B.W.; Kramer, P.F.; Feldens, E.G.; Vítolo, M.R.; Feldens, C.A. Relationship between overweight/obesity in the first year of age and traumatic dental injuries in early childhood: Findings from a birth cohort study. Dent. Traumatol. 2017, 33, 465-471. [CrossRef] 